\title{
Late Eocene transgressive sedimentation in the western Swiss Alps: Records of autochthonous and quasi-autochthonous biofacies on a karstic rocky shore
}

\author{
Telm Bover-Arnal *, David Jaramillo-Vogel, Aso Showani, André Strasser \\ Département de Géosciences, Université de Fribourg, Chemin du Musée 6, CH-1700, Fribourg, Switzerland
}

\begin{abstract}
Carbonate karst unconformities represent primary sequence-stratigraphic boundaries but, where sealed by marine sedimentary successions, also signify ancient rocky shores. During the Late Eocene (Priabonian), a shallow sea flooded the deeply karstified and brecciated Cretaceous carbonate bedrocks of the western Swiss Alps. Transgression resulted in the formation of a rocky archipelago of basement highs with elevations of up to $20 \mathrm{~m}$ and dip angles varying from sub-horizontal to sub-vertical. Although rocky coasts are commonly subjected to vigorous waves, strong currents and storm surges, protected and restricted narrow embayments existed between these islands. The new habitats thus created were colonized by intertidal and shallow subtidal macrobiota, which can be grouped into four biofacies associations: 1) endolithic; 2) epilithic; 3) intertidal; and 4) shallow subtidal. The endolithic biofacies corresponds to an impoverished ichnoassemblage composed of Gastrochaenolites and Entobia borings. The epilithic biofacies is made up of well-preserved rocky-shore biota such as oysters and corals exhibiting an encrusting lifestyle. The intertidal biofacies is composed of wholly preserved shells of potamidid gastropods (Tympanotonos? sp.). The biota present in these biofacies are monospecific or show a very poor species diversity. This fact is in agreement with the pioneer character of the organisms and the sheltered and restricted environments they inhabited. The shallow subtidal biofacies has higher diversity and is characterized by dasycladaceans, oysters, cardiid bivalves, potamidid, ampullinid and Campanile giganteum gastropods, echinoids and solitary corals. The transgressive carbonates evolve upwards into sandy limestones and sandstones displaying sedimentary structures formed in high-energy conditions. This progressive lithofacies change coincides with the opening of the coastal system once the irregular palaeotopography was filled. The transgressive deposits reported here are of significance in that they contain remarkable examples of shallow subtidal and intertidal autochthonous and quasi-autochthonous biofacies associations generated in rocky coast and soft-sediment environments. To our knowledge, this is the first study documenting in detail a rocky shore in the Priabonian.
\end{abstract}

\section{Introduction}

Ancient rocky shores represent stratigraphic unconformities, which can record sedimentary breaks of varying temporal duration (up to billion-year scale; e.g., Corcoran, 2008). Their sequence-stratigraphic significance as sequence boundaries, which delimit emerged rocks from transgressive deposits, together with their importance in palaeogeographical, palaeoshoreline, palaeontological and palaeoecological analyses, make these rockgrounds suitable targets for many geological studies (see Johnson, 2006 for a review). However, these hard substrates have often been overlooked in sedimentological and sequence-stratigraphic studies, where detailed portraits of such palaeoreliefs and associated preserved biota and ichnofossils in general are absent.

\footnotetext{
* Corresponding author.

E-mail address: telm.boverarnal@unifr.ch (T. Bover-Arnal).
}

When rockgrounds are flooded during marine transgression, new habitats are created and colonized by organisms adapted to thrive in intertidal and very shallow subtidal environments, which usually are influenced by waves, tides, currents and storm surges of moderate to high energy levels. Consequently, the preservation in the geological record of original in situ biofacies overlying rocky shores is rare (e.g., Surlyk and Christensen, 1974), given that authochtounous communities are commonly swept away or mixed in such physically disturbed environments (e.g., Johnson et al., 2010). Furthermore, because rocky shores are in many cases linear features, the chance to find them exposed in outcrop is relatively small.

The present paper describes a well-preserved stretch of a CretaceousEocene unconformity in excellent and continuous exposures in the Sanetsch area (Helvetic Nappes, western Swiss Alps), where Late Eocene (Priabonian) transgressive coastal deposits overlie Early Cretaceous karstified limestones and relics of Mid-Eocene lateritic palaeosoils. The Priabonian transgression resulted in the formation of a rocky archipelago of basement highs. Between these islands, protected 
and restricted narrow embayments existed. The Priabonian sedimentary deposits in Sanetsch are of importance in that they (a) constitute an illustrative case study of an ancient shoreline overlain by transgressive strata, which may serve as an example for the recognition and analysis of other rocky-shore depositional environments and transgressive sedimentary successions; and (b) were formed in topographic depressions that were generally well-protected and restricted, and thus provide examples of autochthonous and quasiautochthonous carbonate biofacies generated in rocky-shore and soft-sediment settings.

The karstified Cretaceous platform carbonates overlain by Eocene transgressive deposits of the Helvetic Nappes in Switzerland and their lateral equivalents in the Subalpine Chains in France have been widely studied from various points of view, including cartography, palaeogeography, tectonic evolution, sedimentology, stratigraphy and palaeontology (e.g., Brongniart, 1823; Lugeon, 1919; Herb, 1988; Badoux et al., 1990; Weidmann et al., 1991; MenkveldGfeller, 1993, 1994, 1995; Sinclair et al., 1998; Linder, 2005). However, none of these works portrayed this sedimentary record as a rocky shore depositional succession. A search in the geological literature for other Eocene karstic shores leads to a few examples (Johnson, 2006 for review) but, to the best of our knowledge, none of them are of Priabonian age. Therefore, the present study also fills a gap in available data and research in Late Eocene rocky-shore depositional environments.

\section{Geographical and geological setting of the study area}

A regional unconformity of Eocene age overlies the Mesozoic successions of the Swiss and French Alps. This regional erosive surface, which was the result of emersion and continental erosion due to tectonic uplift linked to flexural forebulge migration of the Alpine foreland basins, was flooded during Late Eocene-Oligocene times (Sinclair et al., 1991; Crampton and Allen, 1995; Sinclair et al., 1998). The Priabonian transgression in the Swiss and French Alps has been regarded to be mainly the result of rapid tectonic subsidence associated with normal faulting related to flexural bending, caused by the advancing Alpine thrust front. The presence of transgressive strata in several places in western Switzerland and eastern France reveals the at least regional character of the transgression (e.g., Menkveld-Gfeller, 1995; Sinclair et al., 1998; Zweigel et al., 1998; Linder, 2005). However, Priabonian transgressive phases have been recognized in many European basins and probably affected the entire central para-Tethyan realm (e.g., Hardenbol et al., 1998).

In the Sanetsch area of the Diablerets Nappe (Canton of Valais; western Swiss Alps) (Fig. 1), the transgression is recorded as a Priabonian succession formed by coastal siliciclastic-influenced carbonate deposits, which overlay the highly irregular karstic palaeorelief of the Early Cretaceous (Hauterivian to Aptian) carbonates of the Schrattenkalk Formation and the remains of Mid-Eocene (Bartonian) lateritic soils (Weidmann, 1984; Herb, 1988; Menkveld-Gfeller, 1995; Linder, 2005). These mixed siliciclasticcarbonate deposits correspond to the Sanetsch Formation, which can be subdivided into three members: Diablerets, Tsanfleuron and Pierredar (Menkveld-Gfeller, 1994) (Fig. 2). The basal part of the Diablerets Member is distinguished by a breccia of Bartonian to Early Priabonian age constituted of Schrattenkalk clasts (Herb, 1988; Linder, 2005). Although these fallen Cretaceous rocks have been classically referred as "Roc Champion" conglomerate (Rykken,

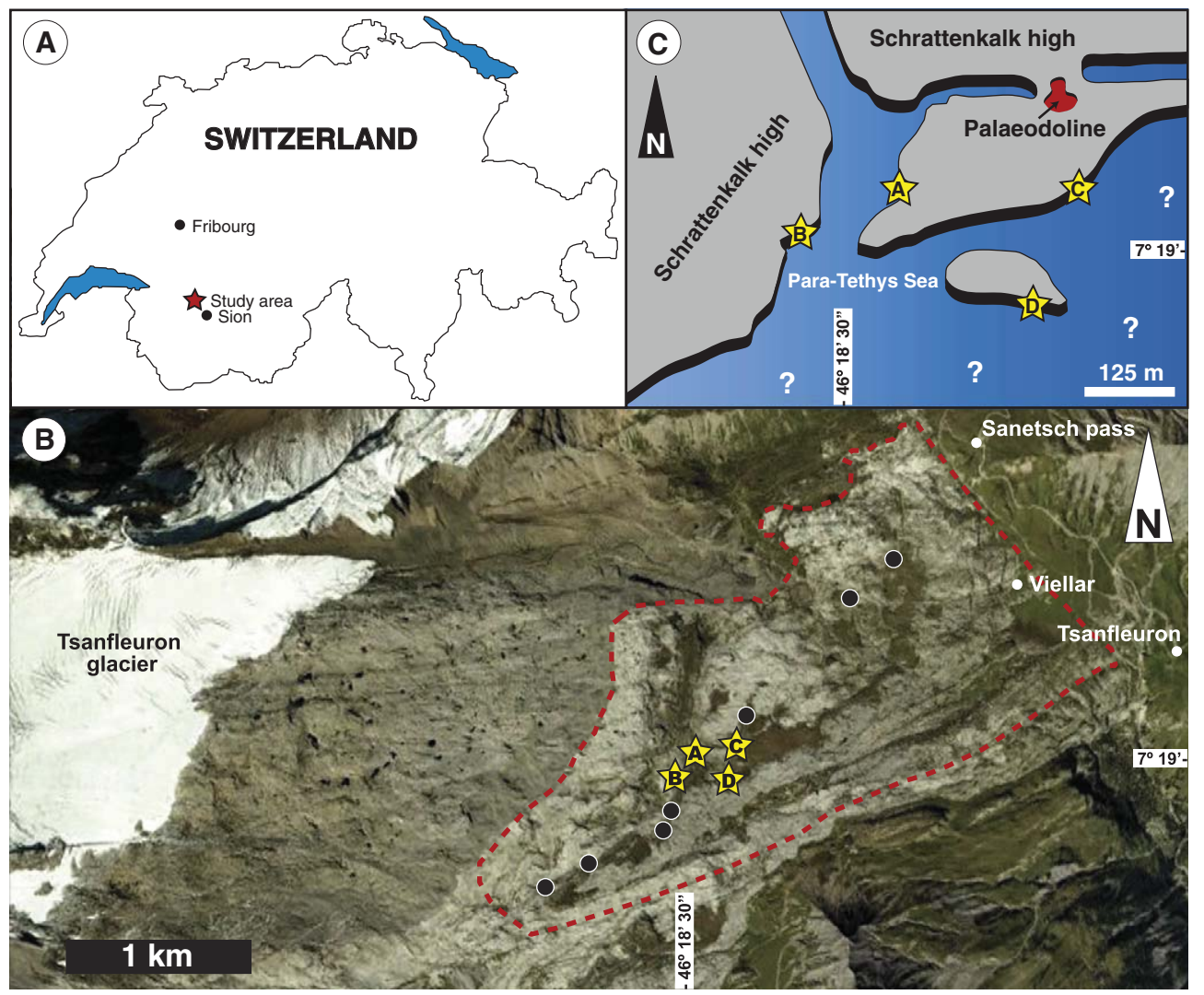

Fig. 1. A) Location of the study site within Switzerland. B) The area investigated in Sanetsch (Canton of Valais, western Swiss Alps) is enclosed with a discontinuous red line. Within the delimited area, the white rocks correspond to the Early Cretaceous limestones of the Schrattenkalk Formation, and the light gray and brown strata constitute respectively the Diablerets and Tsanfleuron members of the Sanetsch Formation. Yellow stars mark the location of representative sedimentary logs shown in Fig. 7. Black dots indicate the situation of the logged sections not illustrated in this study. Background: Google Earth. C) GPS-based schematic reconstruction of the Early Priabonian palaeogeography of the area surrounding the four logs illustrated in Fig. 7. The positions of the four logs are marked with yellow stars. Note the existence of protected narrow embayments between the Schrattenkalk palaeohighs. A palaeodoline filled with Bartonian lateritic palaeosoils (indicated in red) is present in the Schrattenkalk high located to the northeast. 


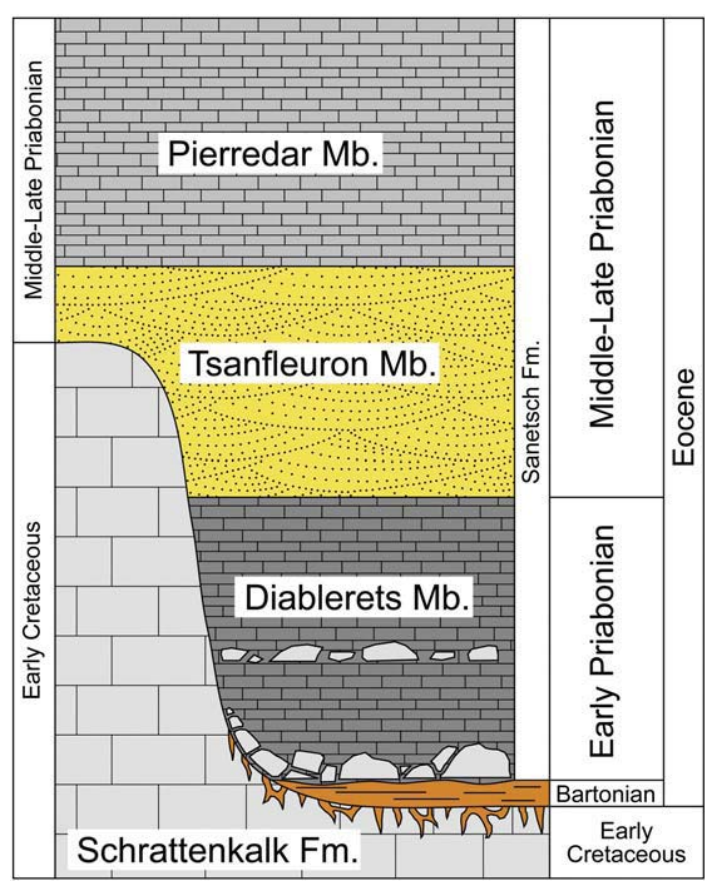

Fig. 2. Simplified stratigraphic chart of the Early Cretaceous and Eocene deposits of the Sanetsch area (western Swiss Alps). The ages of the deposits are based on Herb (1988), Weidmann et al. (1991), Menkveld-Gfeller $(1993,1994,1995)$ and Linder (2005).

1968; Herb, 1988), they constitute in fact a breccia deposit in the Sanetsch area. Above, marine siliciclastic-influenced carbonates and marls of Early Priabonian age compose the rest of the Diablerets
Member (Menkveld-Gfeller, 1995; Linder, 2005). The fossiliferous beds of the Diablerets Member are widely known since the earliest days of geology (e.g., Brongniart, 1823). The Tsanfleuron Member is characterized by extensive sedimentation of sandstones and sandy limestones exhibiting tidally induced sedimentary structures, while the Pierredar Member corresponds to limestones with abundant nummulitids (Rykken, 1968; Menkveld-Gfeller, 1995; Linder, 2005). According to Menkveld-Gfeller (1993, 1994, 1995), these latter lithostratigraphic units are Middle-Late Priabonian in age (Fig. 2).

The sedimentary succession studied here covers an area of $12 \mathrm{~km}^{2}$ and encompasses the Early Cretaceous basement, the Bartonian palaeosoil relics, the Diablerets beds and the lower part of the Tsanfleuron $\mathrm{Mb}$ (Fig. 2). According to the absolute ages of Ogg et al. (2008), the sedimentary gap between the Early Cretaceous Schrattenkalk Fm and the Bartonian laterites in the Sanetsch area comprises a time interval with a duration of at least 70 Myr. For the detailed history of research concerning the Cretaceous and Eocene deposits of the Helvetic Nappes refer to Linder (2005).

\section{Data collection and methods}

The entire stretch of the rocky shore exposed in the Sanetsch area was explored and surveyed. Eleven sedimentary logs of up to $23 \mathrm{~m}$ thick were measured in representative sectors exhibiting significant changes in thickness and/or lithofacies. One hundred two rock samples were collected at vertically spaced decimetric intervals covering the eleven sections. The samples were prepared following standard techniques to produce thin-sections $5-8 \mu \mathrm{m}$ thick with a size of $25 \times 45 \mathrm{~mm}$ in order to analyze the microfacies. Rock fabrics are termed according to the classifications of Dunham (1962) and Embry and Klovan (1971). In addition, nine marl samples were taken in five different sections. The marls were washed, dried and
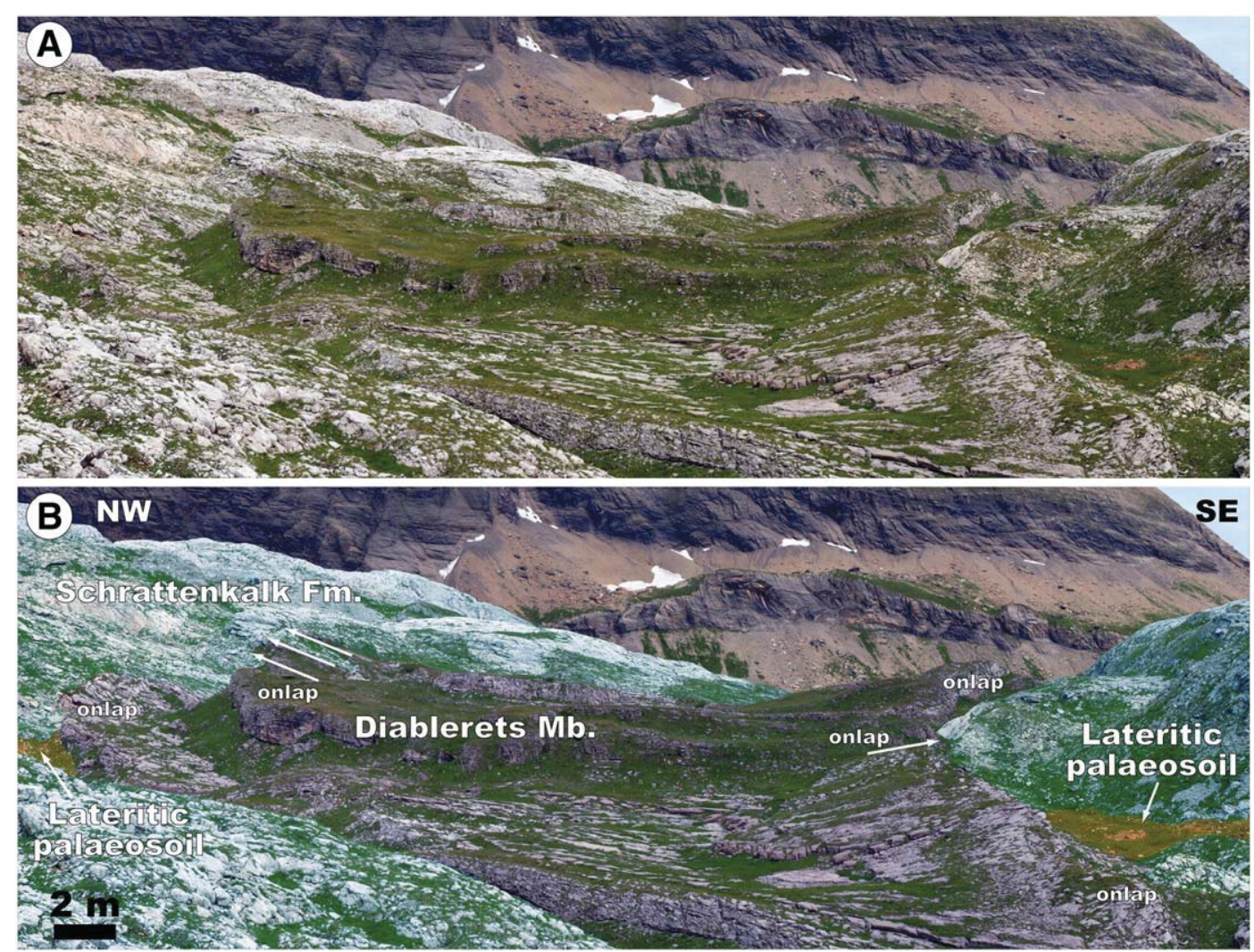

Fig. 3. Contact between the Early Cretaceous basement and the overlying Priabonian marine succession in the eastern study area. A) Field view showing the marine Priabonian succession of the Diablerets Mb banked against the Early Cretaceous rocks of the Schrattenkalk Fm. B) Interpretation of Panel A. Note the lateritic palaeosoils preserved in palaeodolines. 
sieved through six sieves ( $2 \mathrm{~mm}, 1 \mathrm{~mm}, 500 \mu \mathrm{m}, 250 \mu \mathrm{m}, 125 \mu \mathrm{m}$ and $63 \mu \mathrm{m}$ ) in order to determine their fossil content. To reconstruct the Early Priabonian palaeocoastline of the area surrounding the four logs illustrated in this study, GPS coordinates were measured every $5 \mathrm{~m}$ following the contact between the Schrattenkalk Fm and the Diablerets Mb. Subsequently, this data was plotted on a georeferenced topographic map to produce the palaeogeographic model.

\section{Results}

\subsection{Palaeotopography}

Evidence of ancient topography is demonstrated by the occurrence of marine Priabonian limestone strata onlapping heavily karstified Early Cretaceous rocks of the Schrattenkalk Fm (Figs. 3 and 4). The Schrattenkalk basement in the study area corresponds to massive, almost unstructured limestone with packstone to grainstone textures, which contain abundant peloids (Fig. 5A), ooids, orbitolinids, miliolids and other foraminifera, and fragments of rudists, oysters, Chondrodonta, other bivalves, gastropods, corals and green algae. Fissures in the unconformity surface contain abundant Paronipora (=Microcodium). The breccias are composed of pebble- to boulder-sized clasts and karst infillings formed by brownish-reddish fine- to medium-grained siliciclastic sediment (Fig. 5B). The topographic relief exhibited by the karst surface, locally related to sink holes (Figs. 3 and 4), is highly irregular with basement rises of up to $20 \mathrm{~m}$ and dip angles of up to $70^{\circ}$. Relics of iron-rich laterites containing ferruginous pisoids up to $1 \mathrm{~cm}$ of diameter are occasionally preserved at the bottom of palaeodolines (Fig. 5C-D). The lateritic palaeosoils overlying Mesozoic sedimentary successions of the Helvetic Nappes have been classically termed in the literature as 'siderolithic' (e.g., Weidmann et al., 1991; Linder, 2005) and were formed under a warm and humid subtropical climate during the Mid-Eocene
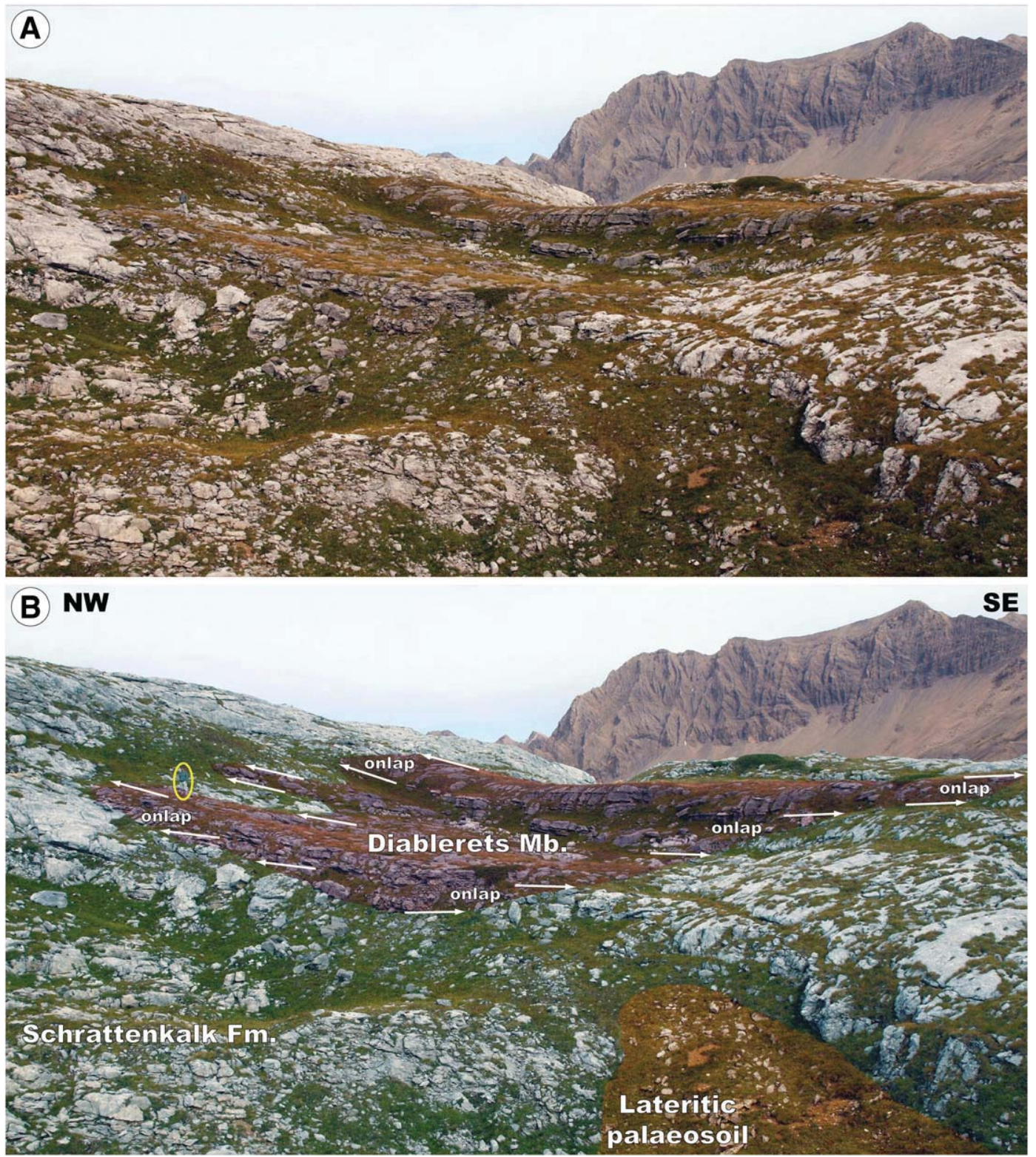

Fig. 4. Contact between the Early Cretaceous bedrocks of the Schrattenkalk Fm and the overlying Late Eocene sedimentary succession in the western study area. A) Outcrop view illustrating how the Diablerets Mb onlaps the Schrattenkalk Fm and how it fills in the pre-existing irregular relief. B) Interpretation of Panel B. Note the presence of lateritic palaeosoils at the bottom of a sink hole; person encircled in yellow $=1.78 \mathrm{~m}$. 

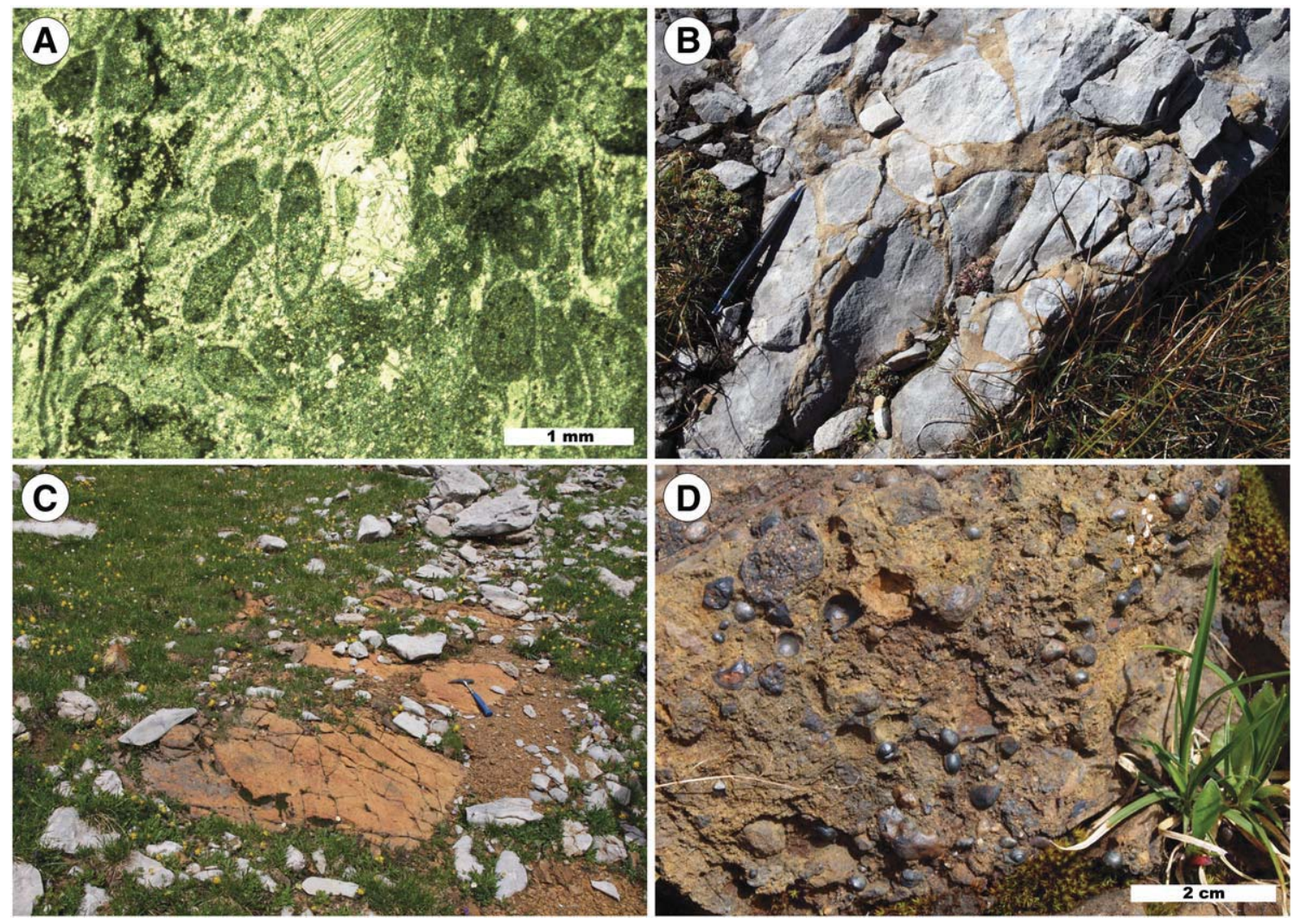

Fig. 5. Sedimentary features of the Early Cretaceous basement and the Bartonian lateritic palaeosoils. A) Photomicrograph of peloidal-skeletal packstone to grainstone microfacies typical of the Schrattenkalk Fm in the Sanetsch area. B) Close-up view of the brecciated top of the Schrattenkalk Fm exhibiting infillings formed by brownish-reddish fine- to medium-grained sediment; pen $=14.4 \mathrm{~cm}$. C) Outcrop view of the Mid-Eocene lateritic soils preserved at the bottom of a palaeodoline; hammer $=32 \mathrm{~cm}$. D) Detail of ferruginous pisoids present in the lateritic palaeosoils.

(Lutetian-Bartonian) phase of emersion and erosion of the Helvetic Nappes (Weidmann, 1984; Herb, 1988; Menkveld-Gfeller, 1995; Linder, 2005).

\subsection{Transgressive sedimentation}

The contact between the transgressive Late Eocene deposits of the Sanetsch Fm and the underlying Early Cretaceous rocks is planar and parallel at the bottom of the palaeotopographic depressions, whereas it is angular on the basement relief. The transgressive sedimentary record is shown in Fig. 6. The successions logged show significant thickness variations and distinct degrees of completeness, which was controlled by the highly irregular relief of the Early Cretaceous bedrocks (Fig. 7).

The basal fill includes a matrix-supported breccia of up to $50 \mathrm{~cm}$ thick composed of Schrattenkalk fragments with sizes varying from pebble to boulder (Fig. 8A). In this basal breccia, which belongs to the Diablerets Mb (Linder, 2005) (Fig. 2), the largest observed clasts are $1 \mathrm{~m}$ across their long axis, but the majority is within the range of $2 \mathrm{~cm}$ to $30 \mathrm{~cm}$ (Fig. 8B). Larger-sized clasts are commonly found adjacent to the basement palaeocliffs. However, no lateral or vertical grading of clast sizes was observed, implying that the breccia components did not experience transport by waves or currents. Fissures in the extraclasts contain abundant Paronipora (=Microcodium) (Fig. 8C). The matrix of the breccia derives from the Priabonian marine mixed carbonate-siliciclastic sedimentation and the reworking of the Bartonian iron-rich palaeosoils. In the middle and upper parts of the Diablerets $\mathrm{Mb}$, the abundance of Schrattenkalk extraclasts generally diminishes, although their sizes remain very variable (up to $5 \mathrm{~m}$ across their long axis). There, with the exception of a second interval of breccia deposits found in some sections (e.g., logs A and C in Fig. 7), the extraclasts rarely come into contact with one another and appear to float within the stratified transgressive limestones. These occurrences exhibit differential compaction of the surrounding strata (Fig. 8D).

Above the basal breccia, the Diablerets $\mathrm{Mb}$ is characterized by siliciclastic-influenced dm-thick limestone beds (Figs. 6 and 9A) exhibiting wackestone to floatstone textures (Fig. 7), alternating with marly intervals. The sizes of the detritic grains (mostly quartz and feldspars) range between silt and coarse sand, and their shape is mostly subangular and subrounded, although angular forms are also common. The color of the freshly broken limestones and marls is dark gray to black, which is attributed to a high content in finely disseminated organic matter. Framboidal pyrite is common (Fig. 9B). The fossil content of the lower strata of the Diablerets $\mathrm{Mb}$ is dominated by miliolids, ostracodes, regular echinoids, solitary corals, oysters and fragments of other mollusks, and dasycladaceans (Fig. 7). Interbedded $\mathrm{cm}$ - to dm-thick intervals of marls contain in addition coal fragments and characean gyrogonites. Upwards in the succession, the Diablerets beds exhibit increased siliciclastic and organic matter content. The more carbonate-rich lower lithofacies change to an alternation of dm-thick limestone beds with packstone to floatstone textures, sandy limestones and marl intervals (Fig. 7). These organic-rich siliciclastic-influenced limestones and marls are distinguished by the presence of abundant mollusks dominated by potamidid (Tympanotonos? sp.), ampullinid and campanilid (Campanile giganteum) gastropods, Ostrea sp., cardiid bivalves, other bivalves, ostracodes, Lenticulina sp., Borelis sp., Orbitolites sp., other miliolids, other benthic foraminifera, and fragments of the crustacean Carpathocancer triangulatus, echinoids and dasycladaceans such as Clypeina helvetica, Broeckella sp. and 

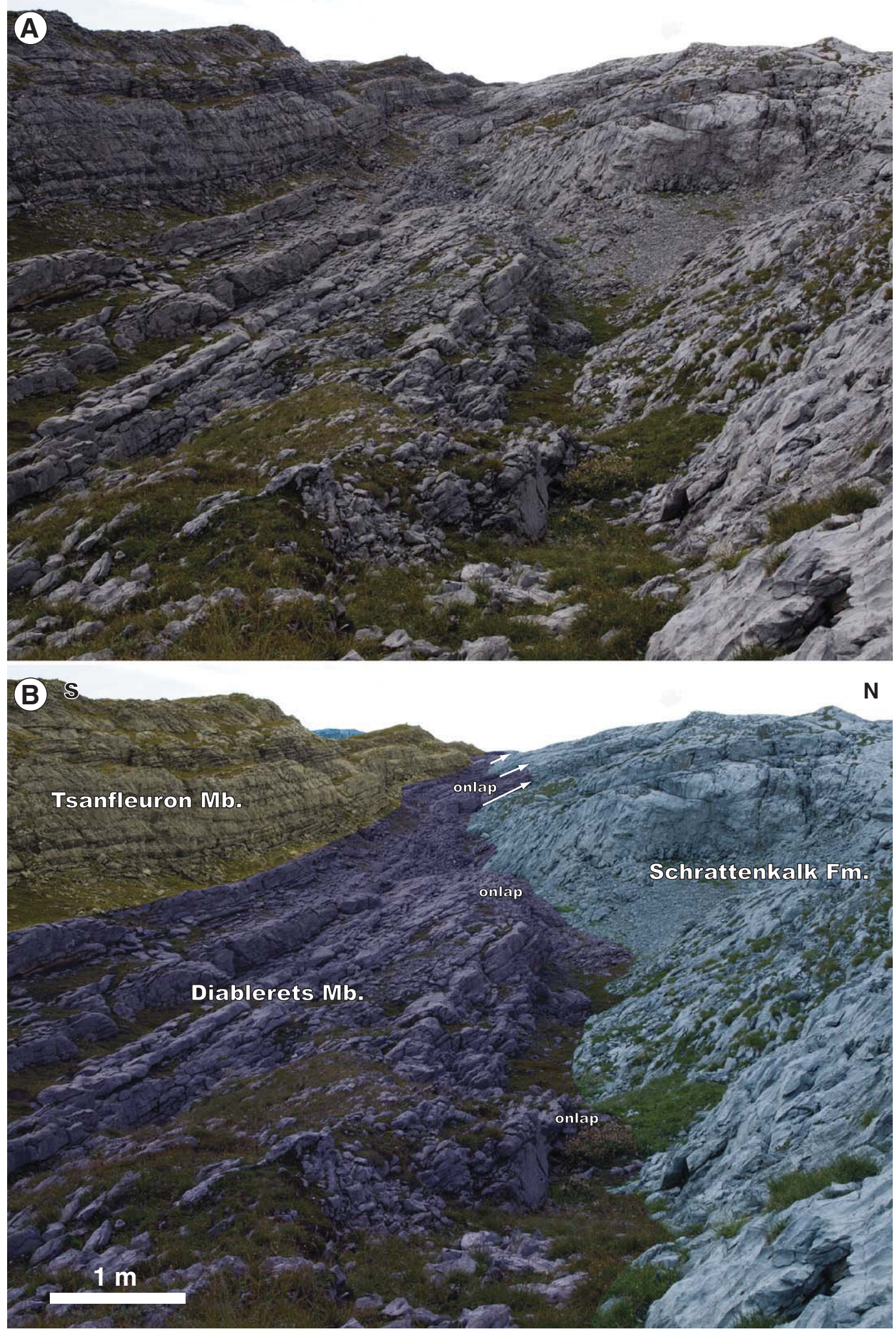

Fig. 6. Contact between the Early Cretaceous limestones of the Schrattenkalk Fm and the overlying Late Eocene Sanetsch Fm at the western study area. A) Outcrop view of the transgressive Priabonian strata (Diablerets and Tsanfleuron members) onlapping the karstified Early Cretaceous rocks of the Schrattenkalk Fm. B) Interpretation of Panel A.

Thrysoporella? sp. Solitary corals, Harrisichara sp. and Nitellopsis sp. characean gyrogonites, planktonic foraminifera such as Chiloguembelina sp., Globigerinatheka sp., Globigerinatheka cf. index (Fig. 9B), Turborotalia cerroazulensis and Turborotalia cocoaensis, and fragments of geniculate coralline algae also occur. Weidmann et al. (1991) also found fragments of turtle shell and teeth of mammals, crocodiles, bony fishes and sharks such as Phyllodus sp. and Nebrius blanckenhorni. Burrow bioturbation is common within the siliciclastic-rich layers. Locally, lenticular centimeterthick sandstone wedges are present. Where the Diablerets beds 


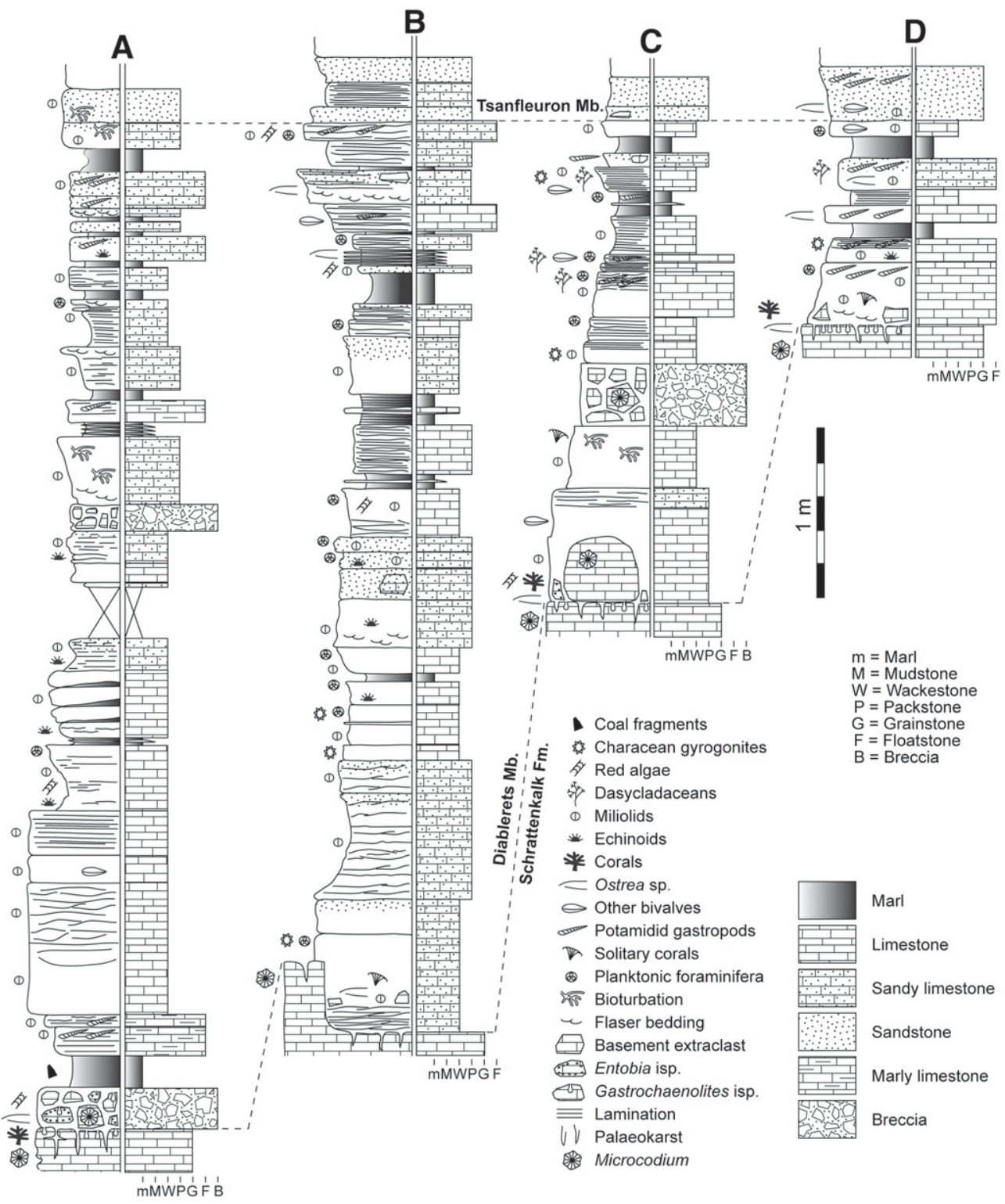

Fig. 7. Correlation of representative sedimentary sections of the Diablerets Mb logged in the Sanetsch area. Note the variation in thickness displayed by the logs. The thickness disparity results from differential accommodation due to the highly irregular topography exhibited by the Schrattenkalk Fm. The situation of the logs is shown in Fig. 1. The rapid facies change to the sandstones of the Tsanfleuron $\mathrm{Mb}$ is considered as isochronous within the study area (horizontal datum line).

are in contact with the Early Cretaceous basement rocks or the basal breccia (Figs. 8A and 9C), the rockgrounds are heavily bored by lithophagid bivalves, and the lithofacies is characterized by a cemented mélange, which includes Cretaceous extraclasts, Bartonian iron-rich relics, bioclastic fragments, Pattalophyllia? sp., other solitary corals, Caulastrea? sp., encrusting coral colonies and oysters (forming bioherms) in life position and wellpreserved dasycladaceans.

The Diablerets beds evolve upwards into the Tsanfleuron $\mathrm{Mb}$, which is composed of $\mathrm{cm}$ - to m-thick sandstone beds exhibiting tidal-influenced structures such as flaser bedding (Fig. 9D), herringbone cross-stratification and foreshore plane-parallel lamination. Grain sizes range between fine sand and gravel, and their shapes are mostly subangular or subrounded, but angular morphologies are present as well. Locally, iron-rich $\mathrm{mm}$ - to $\mathrm{cm}$-sized extraclasts derived from the reworking of Bartonian laterites occur (Fig. 9E). The presence of burrow bioturbation is widespread. Interbedded sandy limestones and more carbonate-rich levels containing Ostrea sp., other bivalves, miliolids, coralline algae (occasionally forming rhodoids; Fig. 9F), irregular echinoids, fragments of mollusks, and other bioclasts are common. In the Sanetsch area, the Tsanfleuron Mb completely buried the Early Cretaceous basement rocks and the Diablerets $\mathrm{Mb}$.

\subsection{Biofacies associations}

Based on the macrofossil biotic communities observed during field work, in sieved marl washings and thin sections, four different biofacies associations indicative of three distinct ecosystems can be discriminated within the Diablerets Mb.

\subsubsection{Endolithic biofacies association}

The ichnodiversity observed along both the Early Cretaceous rocky substrate (Fig. 10A) and the associated breccia deposits is very poor, with only Gastrochaenolites and Entobia borings being present. Gastrochaenolites occurs on both the rockground (Fig. 10B-C) and the rock fragments constituting the basal breccia (Fig. 10D), whereas Entobia was only observed on the breccia clasts and bioclasts 

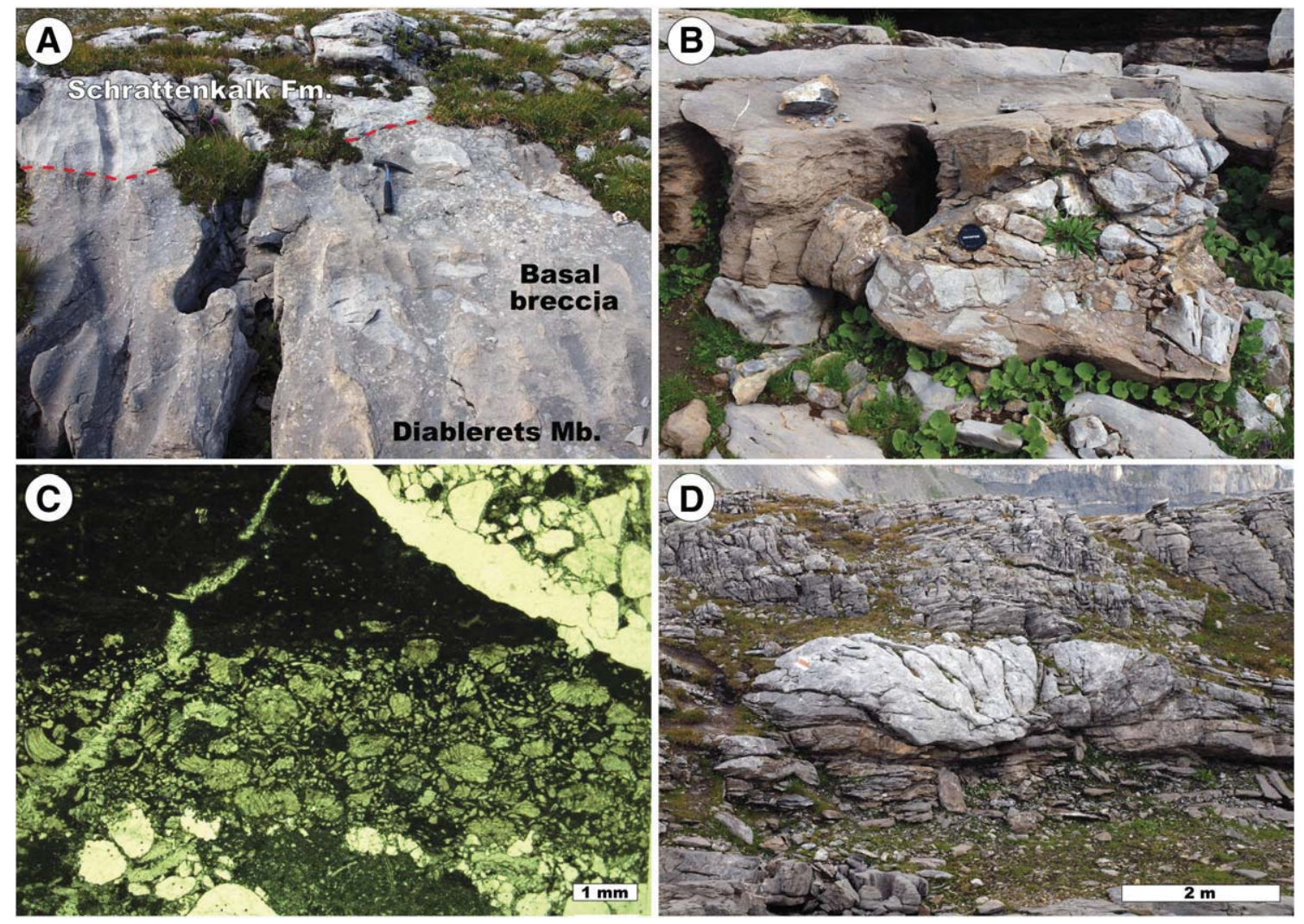

Fig. 8. Sedimentary features and facies of the contact between the Schrattenkalk Fm and the Diablerets Mb. A) Close-up view of the contact. Note the presence of a basal breccia formed by Early Cretaceous extraclasts within a Priabonian matrix; hammer $=32 \mathrm{~cm}$. B) Detail of the breccia present at the base of the Diablerets Mb; camera cap $=5.8 \mathrm{~cm}$. C) Photomicrograph of a fissure in an Early Cretaceous extraclast from the basal part of the Diablerets Mb. Note the presence of abundant Paronipora (= Microcodium). D) Boulder-sized Early Cretaceous extraclast floating within the stratified Diablerets Mb. Note the differential compaction displayed by the underlying and lateral strata.

(Fig. 10E). On limestone rubble and bioclasts, Entobia is the dominant ichnogenus and Gastrochaenolites is less abundant. On account of recent and Eocene chemical and physical erosion, the trace fossils on the surfaces studied show partial to almost total truncation of the original perforations, which were infilled by sediment and calcite cements. This fact hinders the possibility to determine the species of the ichnogenera recognized.

The distribution of these bioerosional structures is irregular with variable densities of Gastrochaenolites and Entobia. On average, 30\% of the clasts and bioclasts belonging to the basal breccia in any given square meter are bored, while only reduced patchy areas of the exposed Early Cretaceous bedrocks are bored. The areas of the semi-vertical basement surface where the Gastrochaenolites are preserved, the borings are mainly oriented perpendicular to the surface and their density rises to over 150 per $\mathrm{m}^{2}$. The limestone rubble and bioclasts forming the basal breccia are typically bored on all sides.

Diameters of spherical and ellipsoidal cavities of Gastrochaenolites produced by lithophagid bivalves are up $20 \mathrm{~mm}$, with an average value of $10 \mathrm{~mm}$. No shells were found inside the borings. Entobia chambers consisting of single and interconnected spherical to ovoid perforations generated by endolithic sponges have a diameter between 1 and $25 \mathrm{~mm}$.

\subsubsection{Epilithic biofacies association}

This biofacies association is made up of well-preserved rockyshore biota exhibiting an encrusting lifestyle (see Johnson, 1988 for review of main lifestyle varieties of rocky-shore biota). Thin-shelled, densely packed monospecific oyster valves (Fig. 11A-B), as well as isolated coral colonies (Fig. 11C-D), occur in growth position cemented to the palaeocliffs and boulders of the Schrattenkalk Fm (Fig. 10A). Oysters also occur attached to other oysters that are directly attached to the Cretaceous substrate, thus forming small bioherms, which can reach heights of $30 \mathrm{~cm}$. No oysters were observed cemented on corals or vice versa. Oyster valves range in size from about 4 to $8 \mathrm{~cm}$ in length, while the coral colonies can reach sizes up to $2 \mathrm{~m}$ across their long axis.

The encrusting coral colonies are diagnostic of shallow subtidal environments while, in comparison with recent analogs, the monospecific oyster biofacies cemented in life position may also have thrived in intertidal settings (e.g., Fournier, 1992; Lejart and Hily, 2011; Scrosati et al., 2011).

\subsubsection{Intertidal soft-sediment biofacies association}

This biofacies corresponds to a low species diversity assemblage, even monospecific, composed of wholly preserved shells of potamidid gastropods (Tympanotonos? sp.), which accumulated within a lime mud matrix in the form of floatstones (Fig. 12A). The length of the snails ranges mainly between 1 and $4 \mathrm{~cm}$. The potamidids are oriented in all directions, not imbricated, and do not show any size gradation, suggesting that they did not undergo significant reworking or transport.

Monospecific high population densities of potamidids are commonly indicative of intertidal settings (e.g., Bandel and Kowalke, 1999; Harzhauser, 2004; Dominici and Kowalke, 2007; Reid et al., 2008; personal observations in Pigeon Creek, San Salvador, Bahamas, Fig. 12B-C), where they graze on detritus and microalgae. Furthermore, the occurrence of such populations is often linked to mangrove ecosystems (e.g., Plaziat et al., 2001; Reid et al., 2008; Fig. 12B). However, no root traces or macrofloral remains were recognized in the nearly monospecific potamidid beds of the Diablerets Mb studied.

\subsubsection{Shallow subtidal soft-sediment biofacies association}

The biota of this association has higher diversity and can be divided into three sub-biofacies, which evolve upwards, or pass laterally, from one to another. The first of these is characterized by well-preserved potamidid shells, which occur associated with diverse taxa such as 

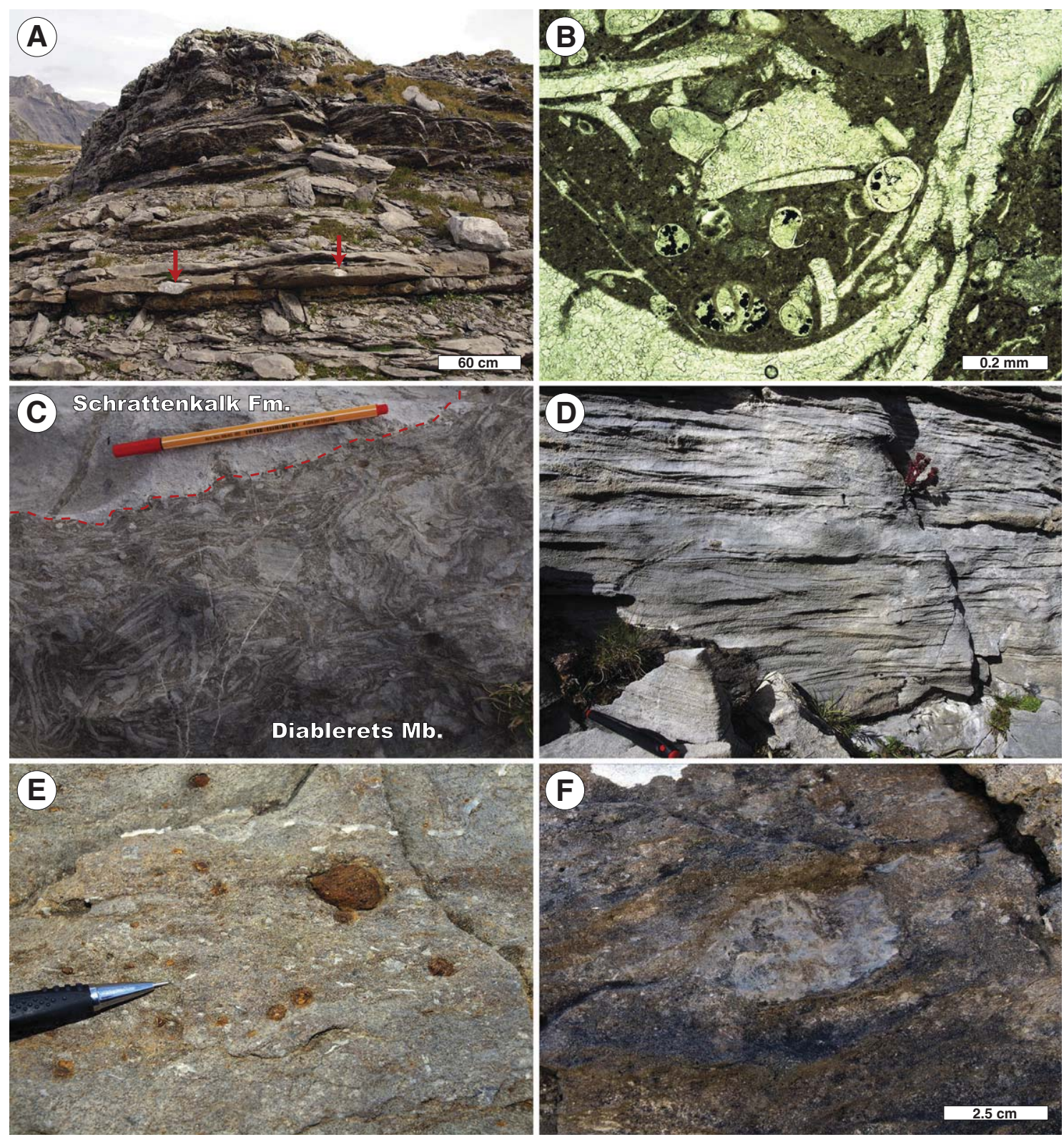

Fig. 9. Sedimentary features and facies of the Sanetsch Fm. A) Outcrop view of the stratified beds of the Diablerets Mb. Red arrows point to Early Cretaceous extraclasts. B) Floatstone of mollusks containing specimens of the planktonic foraminifera Globigerinatheka cf. index (framboidal pyrite within the sparry calcite infillings of their chambers). C) Detail of the contact between the Schrattenkalk Fm and the basal Diablerets Mb, which corresponds to a cemented mélange formed of Cretaceous extraclasts, bioclastic fragments and oyster clusters; pen $=14.4 \mathrm{~cm}$. D) Close-up view of bi-directional foresets and flaser bedding exhibited by the Tsanfleuron Mb; pen =14 cm. E) Detail of iron-rich mm- to cm-sized extraclasts derived from the reworking of Bartonian laterites present in the Tsanfleuron Mb; visible part of pen $=3.9 \mathrm{~cm}$. F) Close-up view of a rhodoid within the sandstones of the Tsanfleuron $\mathrm{Mb}$.

Ostrea (Fig. 12D), cardiid bivalves (Fig. 12E), other bivalves, ampullinids, other gastropods, and the dasycladacean alga Clypeina helvetica (Fig. 12F). The potamidid shells are 1 to $4 \mathrm{~cm}$ long. Ostrea and cardiid bivalves exhibit diameters ranging between 2 and $4 \mathrm{~cm}$. Wholly preserved irregular echinoids in life position associated with solitary corals and/or larger Ostrea, which occasionally occur together with the gastropod Campanile giganteum (Fig. 13A-B), constitute the second sub-biofacies. The echinoids have diameters of around $2 \mathrm{~cm}$, while the oysters and campanilids exhibit lengths of up to 18 and $29 \mathrm{~cm}$, respectively. The third sub-biofacies corresponds to monospecific populations or low-diversity communities of dasycladaceans such as C. helvetica (Fig. 13C), Broeckella sp., Thrysoporella? sp., and rare undiagnosed branching specimens showing an exceptional state of preservation, which reach heights of up to $14.5 \mathrm{~cm}$ (Fig. 13D).
The overall biotic assemblage is preserved mostly within a micritic matrix in the form of floatstones, commonly including siliciclastic components. In the deposits containing echinoids, large Ostrea and/or campanilid gastropods, the fossils float in a sandy matrix.

In this biofacies association, the higher species diversity and the presence of fully marine biota such as dasycladaceans, echinoids, and campanilid gastropods is diagnostic of shallow subtidal habitats (e.g., Dominici and Kowalke, 2007).

\section{Discussion}

Key criteria proving the existence of a rocky shore during the Late Eocene in the Sanetsch area include an angular unconformity between karstified Early Cretaceous and Priabonian marine strata, 

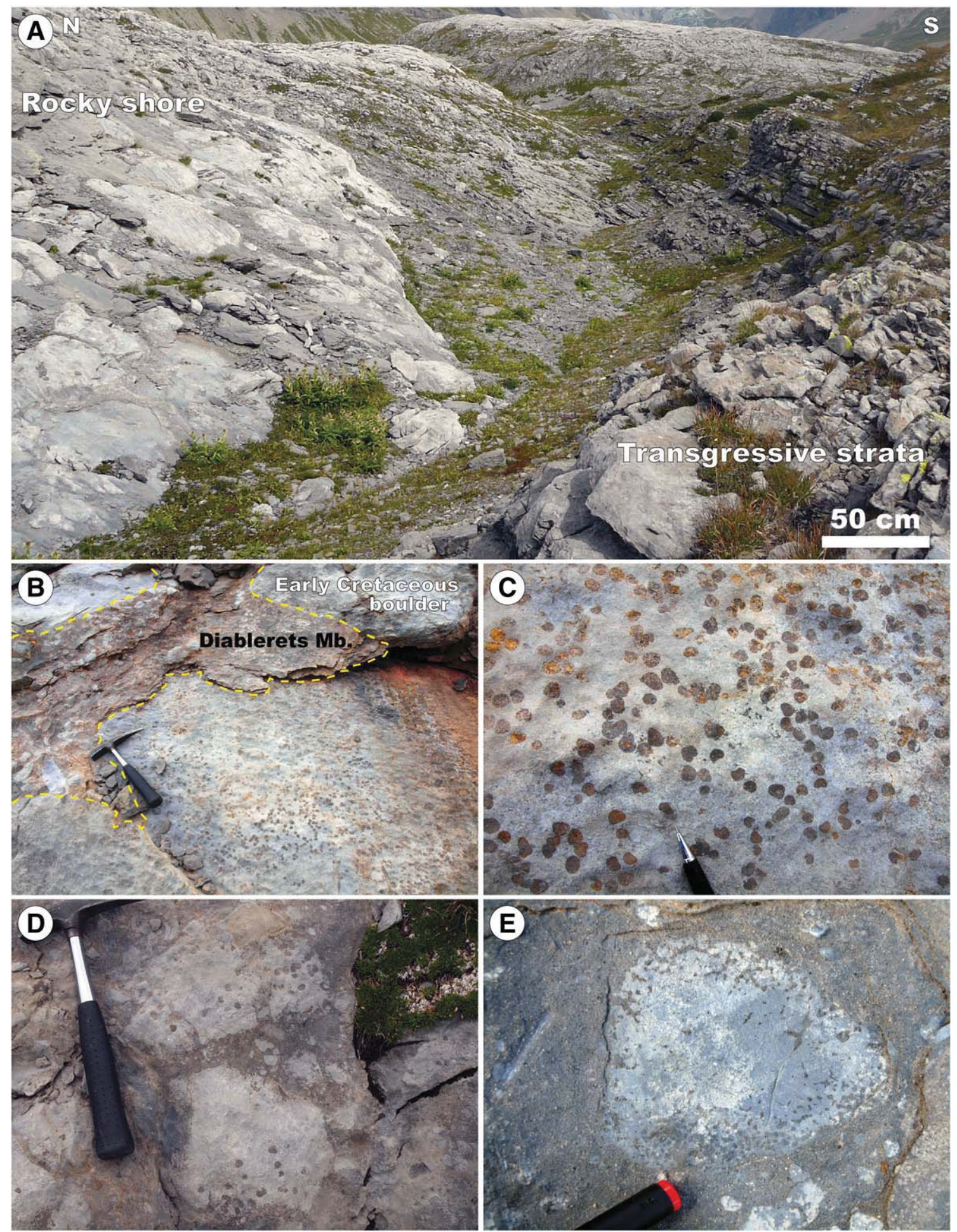

Fig. 10. Photographs of the Priabonian rocky shore and ichnofossil assemblage present on the cliffs and boulders of the Early Cretaceous Schrattenkalk Fm. A) Outcrop view of the Priabonian rocky shore onlapped by the transgressive strata of the Diablerets $\mathrm{Mb}$. Note the patchy aspect of the ancient rocky shore. The white patches correspond to boulders and exposed areas of the Priabonian palaeocliff (Schrattenkalk Fm). The gray patches correspond to oyster bioherms and coral colonies (epilithic biofacies association), which belong to the Diablerets Mb, cemented to the palaeocliff and boulders of the Schrattenkalk Fm. B) Outcrop view of the Schrattenkalk bedrock completely bored by lithophagid bivalves. Note how the basal breccia of the Diablerets $\mathrm{Mb}$ is cemented above the Schrattenkalk Fm; hammer $=32 \mathrm{~cm}$. C) Detail of the iron-impregnated Gastrochaenolites isp. borings shown in Panel B; visible part of pen $=4 \mathrm{~cm}$. D) Close-up view of Early Cretaceous extraclasts of the basal breccia of the Diablerets Mb exhibiting Gastrochaenolites isp. borings; hammer $=$ $32 \mathrm{~cm}$. E) Close-up view of an Early Cretaceous extraclast from the basal Diablerets Mb displaying Entobia isp. bioerosional structures; visible part of pen $=2.2 \mathrm{~cm}$.

the presence of Schrattenkalk extraclasts overlying the karst unconformity or floating within the Priabonian succession, the recognition of marine bioerosion traces and encrusting fauna on the rocks of the Schrattenkalk Fm, and the variable thickness exhibited by the
Diablerets $\mathrm{Mb}$ due to differential accommodation resulting from a pre-existent highly irregular topography (see Johnson, 1988 for a complete review of essential features allowing the identification of ancient rocky shores). The rocky shore is construed to be coeval 

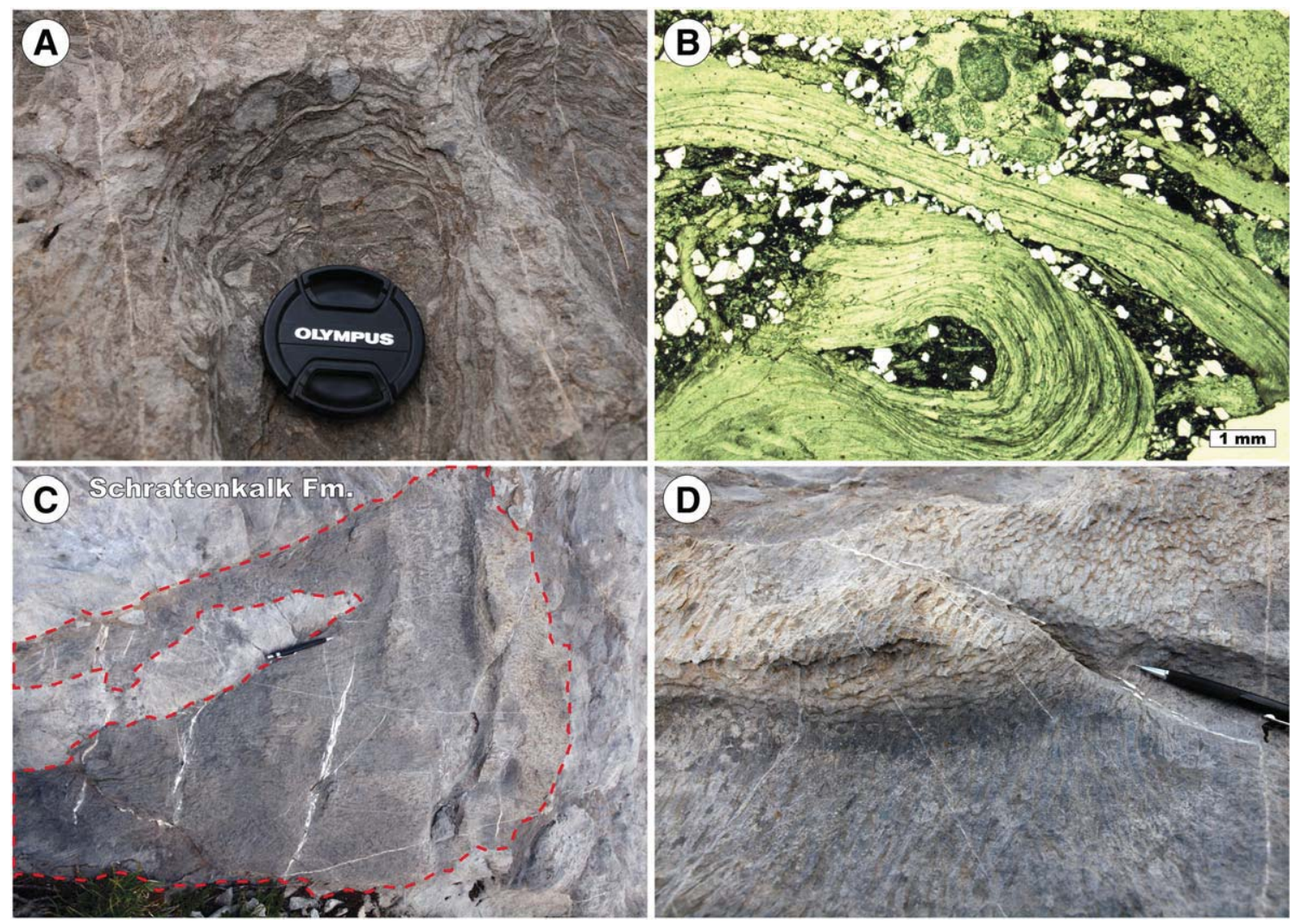

Fig. 11. Illustrations of the epilithic biofacies association of the Diablerets Mb. A) Close-up view of thin, densely packed oyster valves cemented in growth position on a palaeocliff of the Schrattenkalk Fm; camera cap $=5.8 \mathrm{~cm}$. B) Photomicrograph of Fig. 10A. Note the abundance of quartz grains and the presence of an Early Cretaceous extraclast containing peloids and bioclasts (top center). C) Outcrop view of a large irregular massive coral colony encrusting the Schrattenkalk bedrock. The colony is outlined with a dashed red line; pen $=14.4 \mathrm{~cm}$. D) Close-up view of the encrusting coral colony illustrated in Panel C; visible part of pen $=11.2 \mathrm{~cm}$.

with the deposition of the Diablerets Mb, ergo of Priabonian age, given that a prolonged exposure would have removed the ichnospecies and the epilithic body fossils that have been observed.

In the study area, the recognized palaeocliffs are not associated with faults. The palaeorelief exhibited by the Schrattenkalk Fm was rather created by subaerial erosion and pedogenesis than by local tectonics or marine processes. This is indicated by the existence of palaeokarst features and relics of lateritic palaeosoils, and by the absence of wave-cut platforms and notches at the bases of the palaeocliffs. In addition, the bases of the former sea-cliffs display smooth surfaces (Fig. 4), which is characteristic of cliff profiles controlled by subaerial agents (Emery and Kuhn, 1982).

The basal breccia accumulated at the toe of the former cliffs is constituted by angular and irregular-shaped extraclasts (Fig. 8A-B). This and the proximal location of the rock fragments is in agreement with rock fall due to weathering of pre-existing diaclases in the Early Cretaceous limestones. However, with transgression, also wave impact would have played part in loosening joints and thus facilitating the detachment of rock fragments. These considerations can also explain the small breccia deposits and isolated extraclasts, which are found within the transgressive record (Figs. 7, 8D and 9A).

In the Sanetsch area, the pioneers to settle in the new marine rocky habitats were endolithic organisms. The endolithic biota did not fossilize or were eventually eroded, however, their bioerosion trace fossils are widespread throughout the rocky shore and the extraclasts of the basal breccia (Fig. 10B-E). The ichnoassemblage is dominated by Gastrochaenolites and Entobia, which are prolific ichnogenera of Mesozoic to Recent rocky shores (e.g., Bromley and Asgaard, 1993; Gibert et al., 1998; Johnson et al., 2011). The absence of borings or the truncation of the bioerosion structures may result from recent weathering and/or from marine erosion during the
Priabonian. Nevertheless, the lack of perforations at some sites may also imply particular conditions not suitable for the establishment of endolithic biota.

Subsequently, epilithic organisms colonized the rocky shore habitat. The epilithic fossil fauna is not affected by bioerosion structures (Fig. 11) and overlays the trace fossils present at the top of the Schrattenkalk Fm (Fig. 10B). The epilithic biofacies association shows a low diversity with only Ostrea and coral colonies being present (Fig. 11). The specimens are found encrusted in growth position, thus representing autochthonous rocky shore biota.

During the early stages of transgression, accommodation was restricted to palaeotopographic lows. The Priabonian filling of these karst depressions contains characteristic intertidal and very shallow subtidal biofacies associations that are easily discernible in the outcrop (Figs. 12 and 13). The intertidal community corresponds to an autochthonous biofacies given that it is composed of wholly-preserved monospecific specimens of potamidid gastropods (Fig. 12A) and is ecologically consistent with modern analogs (Fig. 12B-C). In addition to the monospecifity and the excellent state of preservation of the fossils, the fact that the shells do not show any sign of size gradation or imbrication but are disposed in all directions, also lends support to the autochthonous nature of the fossil assemblage. The shallow subtidal monospecific assemblages of campanilids (Fig. 13A-B) and dasycladaceans (Fig. 13CD) exhibiting exceptional conditions of preservation are also interpreted to represent autochthonous biofacies. In the case of the shallow subtidal biofacies formed by potamidids associated with Ostrea (Fig. 12D), cardiids (Fig. 12E) and/or dasycladaceans (Fig. 12F), dismantled shells and skeletal fragments are present (e.g., Fig. 12D), indicating slight reworking and transport of the fossils (by tidal currents, storminduced turbulences and/or bioturbation). Nevertheless, given that the assemblage exhibits poor species diversity and most of the biota 

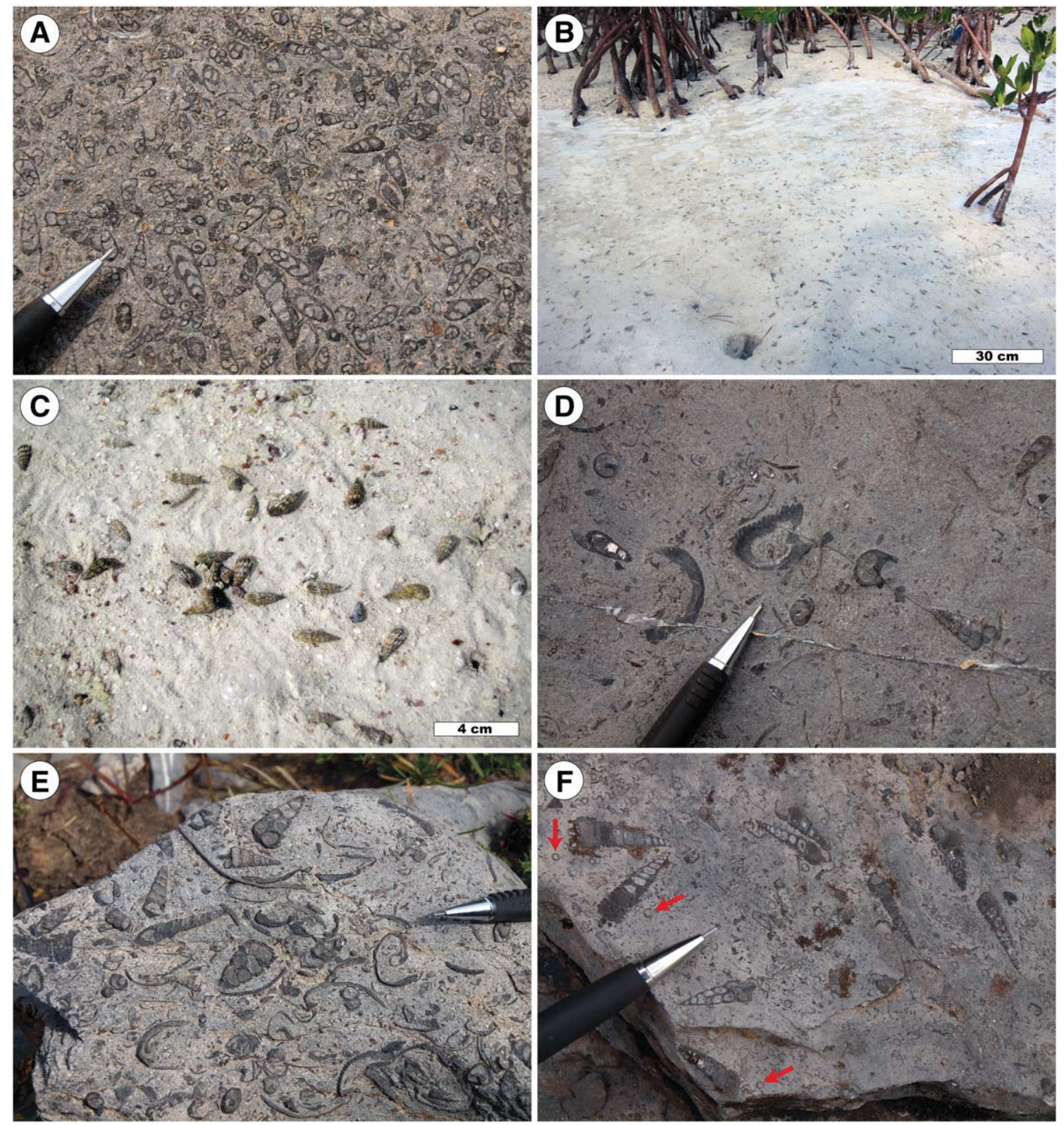

Fig. 12. Illustrations of the soft-sediment intertidal and shallow subtidal biofacies associations of the Diablerets Mb. A) Close-up view of nearly monospecific intertidal biofacies of the Diablerets $\mathrm{Mb}$ constituted by floatstones of potamidid gastropods (Tympanotonos? sp.); visible part of pen $=3.2 \mathrm{~cm}$. B) Recent monospecific high-density population of potamidid gastropods of the genus Cerithidea dwelling on the intertidal mudflat, with adjacent mangroves, at Pigeon Creek (San Salvador, Bahamas). C) Detail of the Cerithidea sp. shown in Panel B. D) Close-up view of shallow subtidal biofacies characterized by floatstones of potamidid gastropods associated with Ostrea sp. and cardiid bivalves; visible part of pen $=4.2 \mathrm{~cm}$. E) Detail of shallow subtidal biofacies distinguished by a floatstone texture containing abundant potamidids and sections of cardiid bivalves; visible part of pen $=3.8 \mathrm{~cm}$. F) Close-up view of shallow subtidal biofacies exhibiting potamidid gastropods together with sections of Clypeina helvetica (red arrows) within a micritic matrix; visible part of pen $=5.1 \mathrm{~cm}$.

is not abraded, these communities were not washed in from more seaward zones but are regarded to reflect quasi-autochthonous biofacies.

The preservation in the sedimentary record of autochthonous and quasi-autochthonous intertidal and shallow-subtidal macrofossil assemblages demonstrates that the Sanetsch area was not an open coastal and erosional environment but mainly a depositional one. Other facts lending support to these sheltered depositional conditions are the lack of features indicating high energy in the surf zone or lower foreshore (e.g., grainstone texture, sediment sorting). Hydrodynamic sedimentary structures within the Diablerets $\mathrm{Mb}$ are rare. Moreover, the extraclasts forming the basal breccia are angular, bored, and encrusted by oysters, which is indicative of lack of strong reworking.
The notion of autochthonous and quasi-autochthonous biofacies in this paper refers exclusively to the macrofossil assemblages described above. The microfossils and the micrite matrix contained in the intertidal and shallow subtidal floatstones were transported by tidal currents and storm-induced turbulences over short distances or - in the case of the planktonic foraminifera - washed in from the open ocean.

Besides the characteristic irregular topographic relief of the Early Cretaceous substrate where autochthonous and quasi-autochthonous coastal biotic elements accommodated, the regional tectonic evolution is also considered to have played part in the preservation of these biofacies assemblages in the sedimentary record. During the Priabonian, flexural downwarping of the Alpine foreland basin, associated with normal faulting, caused rapid tectonic subsidence (Sinclair et al., 

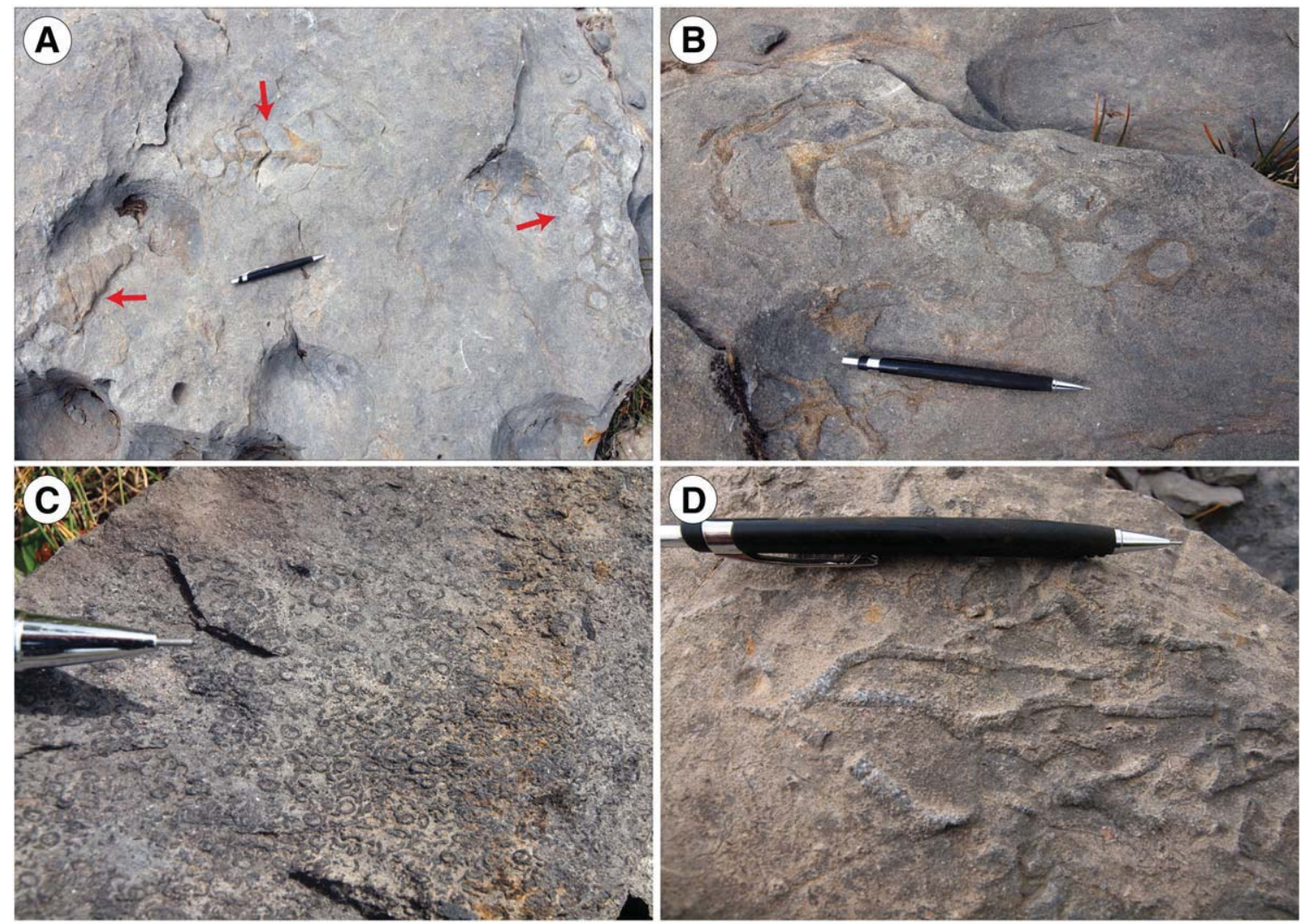

Fig. 13. Illustrations of the shallow subtidal soft-sediment biofacies association. A) Close-up view of Campanile giganteum specimens within a shallow subtidal sandy limestone from the upper part of the Diablerets $\mathrm{Mb}$ (red arrows point to campanilid specimens); pen $=14.4 \mathrm{~cm}$. B) Detail of the Campanile giganteum specimen located at the right side of Panel A pen $=14.4 \mathrm{~cm}$. C) Close-up view of monospecific Clypeina helvetica beds; pen $=1.9 \mathrm{~cm}$. D) Close-up view of an undetermined rare branching dasycladacean alga; pen $=14.4 \mathrm{~cm}$.

1998; Zweigel et al., 1998). Hence, the Diablerets beds would have been buried rapidly (in geological terms), enhancing the preservation potential of these coastal deposits.

The fossil abundance within the Diablerets $\mathrm{Mb}$ is fairly high but species diversity is quite low and even monospecific in some beds, indicating frequent episodes of restricted environmental conditions and water circulation (e.g., varying levels in salinity, oxygenation, and turbidity). Anoxic or dysoxic interstitial waters in the sediment are implied by the organic matter preserved in the dark marls and sandy limestones, and by the presence of framboidal pyrite (Fig. 9B) (Wilkin et al., 1996). On the other hand, the existence of intervals with $\mathrm{cm}$ - to dm-thick carbonate beds points to more favorable conditions for carbonate-producing organisms. However, due to the complex palaeogeography consisting of islands and more or less narrow embayments (Fig. 1C), a significant lateral variability in environmental parameters existed. This is evidenced by the facies changes documented in Fig. 7.

The scarcity of coralline algae and nummulitid and orthophragminid large benthic foraminifera within the Diablerets $\mathrm{Mb}$ is worth noting. In the Middle-Late Eocene, coralline algae and large benthic foraminifera were the main carbonate producing organisms in coastal and platform settings (e.g., Serra-Kiel et al., 2003; Rasser and Piller, 2004; Bassi, 2005; Payros et al., 2010). In the Sanetsch area, the presence of rocky substrates would have provided suitable conditions for the widespread development of coralline algae. However, no algal crusts were found on the basement or around the extraclasts. In this case, the rarity of coralline algae and rhodoids could be linked to the protected and restricted conditions of the depositional environment. Recent (e.g., Johnson et al., 1996) as well as Eocene (e.g., Bassi, 2005; Payros et al., 2010) and other fossil examples (e.g., Johnson and Hayes, 1993) show that the occurrence of red algae is typical of more open marine settings.
Consistently, rhodoids and fragments of coralline algae are common within the high-energy sandstones and sandy limestones of the Tsanfleuron $\mathrm{Mb}$ (Fig. 9F). Therefore, the absence of red-algal encrustations within the Diablerets Mb seems to sustain the existence of a protected depositional setting during the Early Priabonian. Similarly, the absence of large benthic foraminifera such as nummulitids and discocyclinids, which inhabited a broad range of open marine settings, is consistent with a restricted environment (e.g., Racey, 2001). On the other hand, nummulitids and discocyclinids exhibit prolific occurrences throughout the open-marine and deeper limestones of the Pierredar Mb (Fig. 2) (Menkveld-Gfeller, 1994).

Although carbonate deposition occurred within shallow embayments, which were generally protected from high-energy waves and swells of the open ocean by a karstic archipelago (Fig. 1C), the presence of abundant planktonic foraminifera in several levels of the Diablerets Mb (see Fig. 7) indicates periods with close connection to the open ocean. Specimens of Chiloguembelina sp., Globigerinatheka sp., Globigerinatheka cf. index (Fig. 9B), Turborotalia cerroazulensis and Turborotalia cocoaensis were identified. Globigerinatheka index, Turborotalia cerroazulensis and Turborotalia cocoaensis have a stratigraphic range comprising the Middle-Late Eocene interval (Pearson et al., 2006; Premoli Silva et al., 2006) in accordance with the Priabonian age assigned to the Diablerets $\mathrm{Mb}$.

Turborotalia cerroazulensis and Turborotalia cocoaensis inhabited warm waters from low latitudes (Spezzaferri et al., 2002). The occurrence of these planktonic foraminifera is in agreement with the presence of tropical to subtropical biota such as dasycladaceans, potamidids and campanilids (e.g., Dominici and Kowalke, 2007; Reid et al., 2008). On the other hand, Globigerinatheka index has been interpreted to be typical of temperate to cold waters from middle-high latitudes (Spezzaferri et al., 2002). Accordingly, the 
(D)

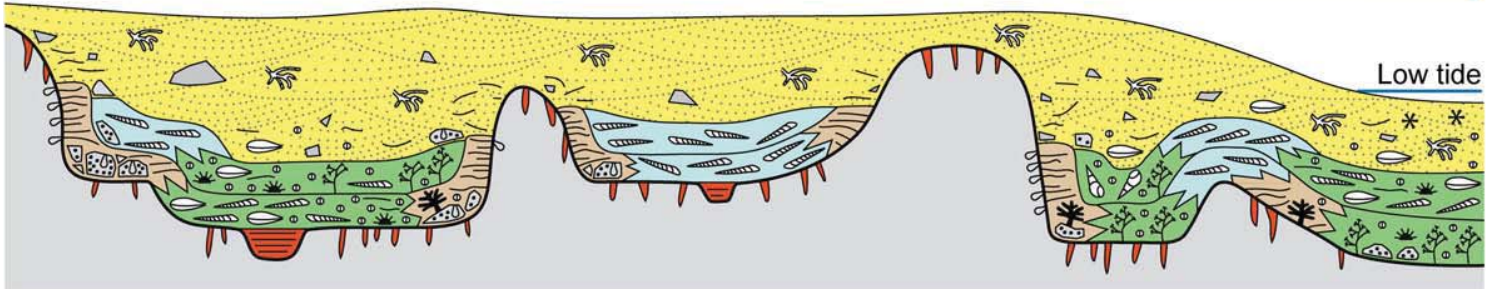

C

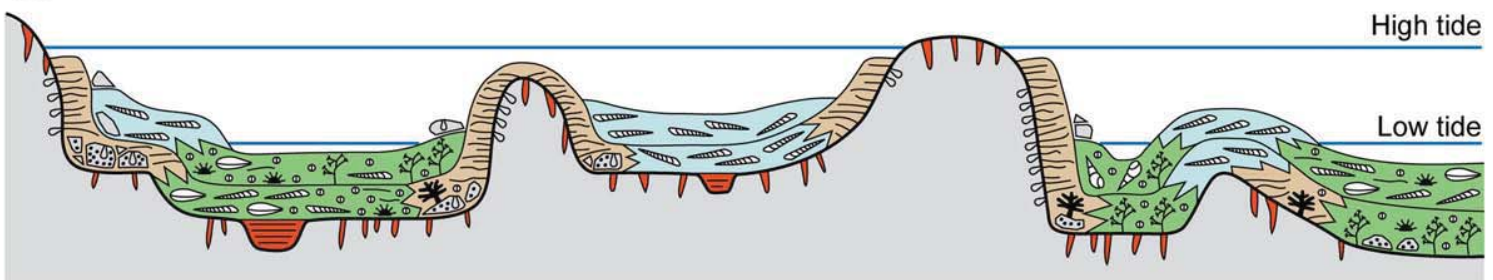

B
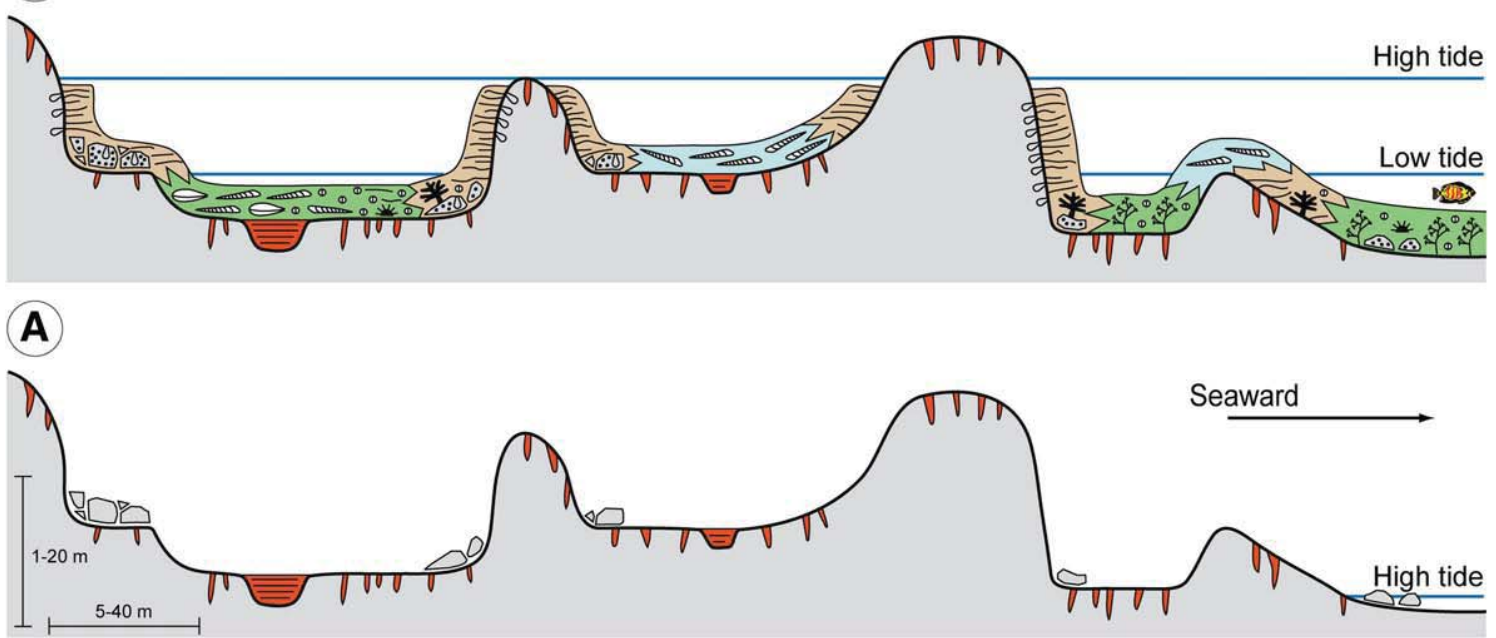

Key

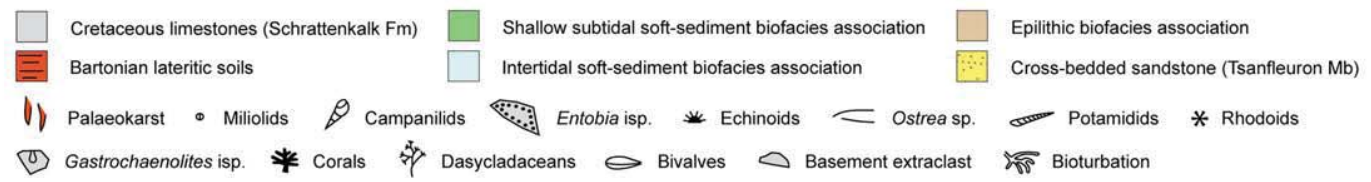

Fig. 14. Two-dimensional schematic model displaying the depositional evolution in the area of Sanetsch during the Priabonian transgression. Take into consideration that in the three dimensions the restricted embayments are connected to the open ocean. A) Exposed Early Cretaceous limestones of the Schrattenkalk Fm. Note the highly irregular karstic unconformity exhibited by the basement and the presence of Bartonian lateritic palaeosoils at the bottom of topographic depressions. Note also the occurrence of Schrattenkalk extraclasts accumulated at the toe of the basement highs. B) The Priabonian transgression starts and restricted, protected and narrow embayments form between the basement highs. Note how rocky-shore and soft-sediment intertidal and very shallow subtidal biota, belonging to the endolithic, epilithic, intertidal and shallow subtidal biofacies associations, colonize the new habitats created. The marine deposits correspond to the Diablerets Mb. C) As relative sea level continues to rise, the irregular palaeotopography shaped on the Schrattenkalk Fm is progressively filled. D) The deposition of cross-bedded sandy limestones and sandstones marks the opening of the system once the irregular karstic depressions are filled. These high-energy deposits correspond to the Tsanfleuron Mb, which buries the Diablerets Mb and the basement highs of the Schrattenkalk Fm.

biota recognized within the Diablerets $\mathrm{Mb}$ indicate a mixture of two water masses, or alternating warmer and colder surface waters. The co-existence of fossil elements belonging to different water masses could indicate coastal upwelling processes or time-averaged assemblages developed at the onset of the stepwise glaciation of Antarctica, and coeval with the oceanographic reorganization proposed for the Late Eocene (e.g., Spezzaferri et al., 2002; Katz et al., 2008; Miller et al., 2009).

The repetitive pulses of siliciclastic input and/or carbonate productivity observed throughout the Diablerets Mb (Fig. 7) could be the result of high-frequency climate changes and/or of relative sealevel oscillations. However, the irregular stacking pattern displayed by the transgressive sedimentary succession does not lead to conclusive evidence. Furthermore, autocyclic processes could have also been important in controlling sediment distribution.

The presence of coal fragments in the lower marly intervals of the Diablerets Mb (Fig. 7) indicates that vegetated areas existed nearby. The repetitive occurrence of characean gyrogonites points to the existence of nearby lakes or freshwater ponds.

Quartz is widespread throughout the Diablerets and Tsanfleuron members (Figs. 7, 9D-F and 11B). During the deposition of the Diablerets beds, siliciclastics were probably brought into the small and narrow embayments of the Sanetsch area by terrestrial runoff, tidal currents and storm-induced turbulences. The transition from the 
siliciclastic-influenced limestones of the Diablerets $\mathrm{Mb}$ to the terrigenous-dominated high-energy sandstones and sandy limestones of the Tsanfleuron Mb (Figs. 2 and 6) does not reflect a fall in relative sea level that would have enhanced the erosion rate: due to the intertidal and very shallow subtidal nature of the Diablerets $\mathrm{Mb}$, a relative sea-level drop in the Middle Priabonian would have led to subaerial exposure instead of accommodating the Tsanfleuron Mb. Therefore, it seems likely that a river delta must have existed nearby that furnished large amounts of siliciclastics. This possibility is supported by the presence of the Early-Middle Priabonian, thus coeval, deltaic sandstones of the Hohgant Fm, which crops out in the eastern part of the closeby Wildhorn Nappe (Menkveld-Gfeller, 1994). Once the topographic depressions of the Sanetsch area were filled, the system opened and tidal and longshore currents probably transported the sands towards the Sanetsch area. Accordingly, the sandstones and sandy limestones of the Tsanfleuron $\mathrm{Mb}$ exhibit hydrodynamic sedimentary structures (Fig. 9D). The overall depositional evolution of the Diablerets and Tsanfleuron members during the Priabonian transgressive phase is summarized in Fig. 14.

\section{Conclusions}

During the Late Eocene, the highly irregular karstified and brecciated relief of the Early Cretaceous bedrocks of the Helvetic Nappes was flooded by a shallow sea. In the Sanetsch area (western Swiss Alps), transgression generated narrow, protected and restricted embayments between basement highs of up to $20 \mathrm{~m}$ height. The newly created intertidal and very shallow subtidal habitats were colonized by monospecific populations or lowdiversity biotic communities. The low species richness is in accordance with the generalistic character of extant relatives of the Sanetsch fossil biota and with a sheltered and restricted environment. The macrobiota contained within the transgressive Priabonian strata can be classed into four biofacies associations with distinct palaeoecological significance: 1) Endolithic; 2) Epilithic; 3) Intertidal; and 4) Shallow subtidal. The trace fossil assemblage observed on the basement surface and on the associated breccia clasts is dominated by the ichnogenera Gastrochaenolites and Entobia. The epilithic biofacies association is distinguished by encrusting Ostrea and coral colonies. The intertidal biofacies association is characterized by a monospecific soft-sediment assemblage of potamidid gastropods. The shallow subtidal biofacies association includes a higher species diversity including potamidids, ampullinids, campanilids, dasycladaceans, cardiids, Ostrea and irregular sea urchins. All these biotic associations, which were usually protected from waves, currents and storm surges by the irregular topography of the Early Cretaceous substratum, frequently sedimented as autochthonous or quasiautochthonous biofacies. Despite of the sheltered conditions of the depositional system, the relatively high abundance of planktonic foraminifera indicates periods of close connection to the open sea. Furthermore, the occurrence of tropical to subtropical fauna such as dasycladaceans, potamidids, and campanilids together with Globigerinatheka index, which is typical of temperate to cold waters, indicates a mixture of two different water masses. The presence of black, organic-rich marly intervals and framboidal pyrite throughout the transgressive record points to recurrent long-lasting episodes of anoxic or dysoxic pore waters. When the irregular palaeorelief was filled, the sheltered coastal system opened and sandstone deposits exhibiting hydrodynamic structures formed. The transgressive record presented here is of significance in that it provides examples of autochthonous and quasi-autochthonous biofacies associations, which were formed on a rocky-shore and in intertidal and shallow-subtidal soft-sediment environments. Finally, to our knowledge, this is the first detailed report of a Priabonian rocky shore.

\section{Acknowledgements}

Stefano Dominici, Felix Schlagintweit, Silvia Spezzaferri, Jean-Pierre Berger, Carles Martín-Closas, and German Àlvarez are greatly thanked for determining several fossil specimens and providing useful advice, as well as bibliography, on their palaeoecology. Jon Mosar provided valuable information on the regional geology. Stefano Dominici and an anonymous reviewer are thanked for their comments and suggestions, which helped to improve the initial version of the manuscript. Financial support for this study came from the Swiss National Science Foundation grant no. 20-121545.08.

\section{References}

Badoux, H., Gabus, J.-H., Mercanton, C.-H., 1990. Feuille Les Diablerets et notice explicative (2 ème édition), Atlas géol. de la Suisse au 1:25.000. Comm. Géol. Suisse. 63 p. Bandel, K., Kowalke, T., 1999. Gastropod fauna of the Cameroonian coasts. Helgoland Marine Research 53, 129-140.

Bassi, D., 2005. Larger foraminiferal and coralline algal facies in an Upper Eocene storm-influenced, shallow-water carbonate platform (Colli Berici, north-eastern Italy). Palaeogeography, Palaeoclimatology, Palaeoecology 226, 17-35.

Bromley, R.G., Asgaard, U., 1993. Endolithic community replacement on a Pliocene rocky coast. Ichnos 2, 93-116.

Brongniart, A., 1823. Mémoire sur les terrains de sédiment supérieurs calcaréo-trappéens du Vicentin: et sur quelques terrains d'Italie, de France, d'Allemagne, etc., qui peuvent se rapporter a la même époque. F.G. Levrault, Paris. 86 p.

Corcoran, P.L., 2008. Ordovician paleotopography as evidenced from original dips and differential compaction of dolostone and shale unconformably overlying Precambrian basement on Manitoulin Island, Canada. Sedimentary Geology 207, 22-33.

Crampton, S.L., Allen, P.A., 1995. Recognition of forebulge unconformities associated with early stage foreland basin development: example from the north Alpine foreland basin. Bulletin of the American Association of Petroleum Geologists Bulletin 79, 1495-1514.

Dominici, S., Kowalke, T., 2007. Depositional dynamics and the record of ecosystem stability: Early Eocene faunal gradients in the Pyrenean foreland, Spain. Palaios 22, 268-284.

Dunham, R.J., 1962. Classification of carbonate rocks according to depositional texture. In: Ham, W.E. (Ed.), Classification of Carbonate Rocks: Am. Assoc. Petrol. Geol. Mem., 1, pp. 108-121.

Embry, A.F., Klovan, J.E., 1971. A Late Devonian reef tract on northeastern Banks Island, N.W.T. Bulletin of Canadian Petroleum Geology 19, 730-781.

Emery, K.O., Kuhn, G.G., 1982. Sea cliffs: their processes, profiles, and classification. Geological Society of America Bulletin 93, 644-654.

Fournier, M.-L., 1992. The reproductive biology of the tropical rocky oyster Ostrea iridescens (Bivalvia: Ostreidae) on the Pacific coast of Costa Rica. Aquaculture 101, 371-378.

Gibert, J.M., Martinell, J., Domènech, R., 1998. Entobia ichnofacies in fossil rocky shores, Lower Pliocene, northwestern Mediterranean. Palaios 13, 476-487.

Hardenbol, J. Thierry, J. Farley, M.B., Jacquin, T., De Graciansky, P.-C., Vail, P.R., 1998 Mesozoic and Cenozoic sequence chronostratigraphic framework of European Basins. In: De Graciansky, P.-C., Hardenbol, J., Jacquin, T., Vail, P.R., Farley, M.B. (Eds.), Mesozoic and Cenozoic Sequence Stratigraphy of European Basins: SEPM Special Publication, 60.

Harzhauser, M., 2004. Oligocene gastropod faunas of the Eastern Mediterranean (Mesohellenic Trough/Greece and Esfahan-Sirjan Basin/Central Iran). Courier Forschungs-Institut Senckenberg 248, 93-181.

Herb, R., 1988. Eocaene Paläogeographie und Paläotektonik des Helvetikums. Eclogae Geologicae Helvetiae 81, 611-657.

Johnson, M.E., 1988. Hunting for ancient rocky shores. Journal of Geological Education 36, 147-154.

Johnson, M.E., 2006. Uniformitarianism as a guide to rocky-shore ecosystems in the geological record. Canadian Journal of Earth Sciences 43, 1119-1147.

Johnson, M.E., Hayes, M.L., 1993. Dichotomous facies on a Late Cretaceous Rocky Island as related to wind and wave patterns (Baja California, Mexico). Palaios 8, 385-395.

Johnson, M.E., Ledesma-Vázquez, J., Clark, H.C., Zwiebel, J.A., 1996. Coastal evolution of Late Cretaceous and Pleistocene rocky shores: Pacific rim of northern Baja California Mexico. Geological Society of America Bulletin 108, 708-721.

Johnson, M.E., Karabinos, P.M. Mendia, V., 2010. Quaternary intertidal deposits intercalated with volcanic rocks on Isla Sombrero Chino in the Galápagos Islands (Ecuador). Journal of Coastal Research 26, 762-768

Johnson, M.E., Gudveig Baarli, B., Santos, A., Mayoral, E., 2011. Ichnofacies and microbial build-ups on Late Miocene rocky shores from Menorca (Balearic Islands), Spain. Facies 57, 255-265.

Katz, M.E., Miller, K.G., Wright, J.D., Wade, B.S., Browning, J.V., Cramer, B.S., Rosenthal, Y., 2008. Stepwise transition from the Eocene greenhouse to the Oligocene icehouse. Nature Geoscience 1, 329-334.

Lejart, M., Hily, C., 2011. Differential response of benthic macrofauna to the formation of novel oyster reefs (Crassostrea gigas, Thunberg) on soft and rocky substrate in the intertidal of the Bay of Brest, France. Journal of Sea Research 65, 84-93.

Linder, P., 2005. An Eocene paleodoline in the Morcles Nappe of Anzeindaz (Canton of Vaud, Switzerland). Eclogae Geologicae Helvetiae 98, 51-61. 
Lugeon, M., 1919. Sur le sidérolithique de la Cordaz (Alpes vaudoises). Bull. Soc. Vaud. Sci. Nat., 52, pp. $109-110$

Menkveld-Gfeller, U., 1993. Stratigraphie und Paläogeographie des Eocaens der helvetischen Decken der Westschweiz (Diablerets- und Wildhorn-Decke). Unpublished PhD thesis, University of Bern, 105 p.

Menkveld-Gfeller, U., 1994. Die Wildstrubel-, die Hohgant- und die SanetschFormation: Drei neue lithostratigraphische Einheiten des Eocaens der helvetischen Decken. Eclogae Geologicae Helvetiae 87, 789-809.

Menkveld-Gfeller, U., 1995. Stratigraphie, Fazies und Palaeogeographie des Eocaens der helvetischen Decken. Eclogae Geologicae Helvetiae 88, 115-134.

Miller, K.G., Wright, J.D., Katz, M.E., Wade, B.S., Browning, J.V., Cramer, B.S., Rosenthal, Y., 2009. Climate threshold at the Eocene-Oligocene transition: Antarctic ice sheet influence on ocean circulation. In: Koeberl, C., Montanari, A. (Eds.), The Late Eocene EarthHothouse, Icehouse, and Impacts: GSA Special Paper, 452, pp. 169-178.

Ogg, J.G., Ogg, G., Gradstein, F.M., 2008. The Concise Geologic Time Scale. Cambridge University Press, Cambridge, UK. 184 p.

Payros, A., Pujalte, V., Tosquella, J., Orue-Etxebarria, X., 2010. The Eocene stormdominated foralgal ramp of the western Pyrenees (Urbasa-Andia Formation): an analogue of future shallow-marine carbonate systems? Sedimentary Geology 228, 184-204.

Pearson, P.N., Premec-Fucek, V., Premoli Silva, I., 2006. Taxonomy, biostratigraphy, and phylogeny of Eocene Turborotalia. In: Pearson, P.N., Olsson, R.K., Huber, B.T., Hemleben, C., Berggren, W.A. (Eds.), Atlas of Eocene Planktonic Foraminifera. Cushman Foundation for Foraminiferal Research: Special Publication, 41, pp. 433-460.

Plaziat, J.-C., Cavagnetto, C., Koeniguer, J.-C., Baltzer, F., 2001. History and biogeography of the mangrove ecosystem, based on a critical reassessment of the paleontological record. Wetlands Ecology and Management 9, 161-179.

Premoli Silva, I., Wade, B.S., Pearson, P.N., 2006. Taxonomy, biostratigraphy, and phylogeny of Globigerinatheka and Orbulinoides. In: Pearson, P.N., Olsson, R.K., Huber, B.T., Hemleben, C., Berggren, W.A. (Eds.), Atlas of Eocene Planktonic Foraminifera. Cushman Foundation for Foraminiferal Research: Special Publication, 41, pp. 169-212.

Racey, A., 2001. A review of Eocene nummulite accumulations: structure, formation and reservoir potential. Journal of Petroleum Geology 24, 79-100.

Rasser, M.W., Piller, W.E., 2004. Crustose algal frameworks from the Eocene Alpine Foreland. Palaeogeography, Palaeoclimatology, Palaeoecology 206, 21-39.
Reid, D.G. Dyal, P., Lozouet, P. Glaubrecht, M. Williams, S.T, 2008. Mudwhelks and mangroves: the evolutionary history of an ecological association (Gastropoda: Potamididae). Molecular Phylogenetics and Evolution 47, 680-699.

Rykken, J., 1968. The nummulithic of the Nappe de Morcles. Mém. Soc. Vaud. Sci. Nat., 89, pp. 193-232.

Scrosati, R.A., van Genne, B., Heaven, C.S., Watt, C.A., 2011. Species richness and diversity in different functional groups across environmental stress gradients: a model for marine rocky shores. Ecography 34, 151-161.

Serra-Kiel, J., Mató, E., Travé, A., Ferràndez-Cañadell, C., Busquets, P., Samsó, J.M., Tosquella, J., Barnolas, A., Àlvarez-Pérez, G., Franquès, J., Romero, J., 2003. An inventory of the marine and transitional Middle/Upper Eocene deposits of the southeastern Pyrenean foreland basin (NE Spain). Geologica Acta 1, 201-229.

Sinclair, H.D., Coakley, B.J., Allen, P.A., Watts, A.B., 1991. Simulation of foreland basin stratigraphy using a diffusion model of mountain uplift and erosion: an example from the central Alps, Switzerland. Tectonics 10, 599-620.

Sinclair, H.D., Sayer, Z.R., Tucker, M.E., 1998. Carbonate sedimentation during early foreland basin subsidence: the Eocene succession of the French Alps. In: Wright, V.P., Burchette, T.P. (Eds.), Carbonate Ramps: Geol. Soc. Spec. Pub., 149, pp. 205-227.

Spezzaferri, S., Basso, D. Coccioni, R., 2002. Late Eocene planktonic foraminiferal response to an extraterrestrial impact at Massignano GSSP (northeastern Appennines, Italy). Journal of Foraminiferal Research 32, 188-199.

Surlyk, F., Christensen, W.K., 1974. Epifaunal zonation on an Upper Cretaceous rocky coast. Geology 2, 529-534.

Weidmann, M., 1984. Paléokarst éocène dans l'Autochtone chablaisien (VS et VD). Bull. Murithienne 102, 119-127.

Weidmann, M., Franzen, J., Berger, J.-P., 1991. Sur l'âge des Couches à Cérithes ou Couches des Diablerets de l'Eocène alpin. Eclogae Geologicae Helvetiae 84, 893-919.

Wilkin, R.T., Barnes, H.L., Brantley, S.L., 1996. The size distribution of framboidal pyrite in modern sediments: an indicator of redox conditions. Geochimica et Cosmochimica Acta 60, 3897-3912.

Zweigel, T., Aigner, T., Luterbacher, H., 1998. Eustatic versus tectonic controls on Alpine foreland basin fill: sequence stratigraphy and subsidence analysis in the SE German Molasse. In: Mascle, A., Puigdefàbregas, C., Luterbacher, H.P., Fernàndez, M. (Eds.), Cenozoic Foreland Basins of Western Europe: Geological Society Special Publication, 134, pp. 299-323. 